\title{
Protecting Child Nutritional Status in the Aftermath of a Financial Crisis: Evidence from Indonesia*
}

\author{
John Giles ${ }^{+}$and Elan Satriawan ${ }^{++}$
}

December 5, 2014

\begin{abstract}
In response to concerns over the vulnerability of the young in the wake of Indonesia's 1997-1998 economic crises, the Government of Indonesia implemented a supplementary feeding program to support early childhood nutritional status. This paper exploits heterogeneity in duration of program exposure to evaluate the impact of the program on children aged 6 to 60 months. By examining differences in nutritional status of treated younger children and a placebo group of older children, the analysis finds that the program improved the nutritional status of treated children, and most significantly, led to 7 and 15 percent declines in rates of moderate and severe stunting, respectively, for children aged 12 to 24 months who were exposed to the program for at least 12 months over two years.
\end{abstract}

JEL Codes: I12, I18, O15, O20, O22.

Key Words: Nutritional Interventions, Program Evaluation, Poverty, Financial Crises, Indonesia

\footnotetext{
* This paper has benefitted from comments on earlier versions from Harold Alderman, Richard Bernsten, Alan de Brauw, Jed Friedman, Emanuela Galasso, John Strauss, Duncan Thomas and three anonymous referees. The authors are grateful for support from the Knowledge for Change Program and the Strategic Impact Evaluation Fund at the World Bank. Supplementary appendix materials are available through the journal website, or as appendices in the penultimate drafts of this paper as World Bank Policy Research Working Paper 5471 and as an IZA Discussion Paper.

+ Development Research Group, The World Bank, MSN MC 3-311, 1818 H St NW, Washington, DC, 20433, e-mail: jgiles@worldbank.org and Institute for the Study of Labor (IZA), Bonn, Germany.

${ }^{++}$Fakultas Ekonomi dan Bisnis, Universitas Gadjah Mada, Jl. Humaniora No 1, Bulaksumur, Yogyakarta 55281, Indonesia , e-mail: esatriawan@feb.ugm.ac.id.
} 


\section{Introduction}

With the onset of the global financial and economic crisis in late 2008, concerns were immediately raised over the vulnerability of infants and young children, and the likelihood of increases in infant mortality (Friedman and Schady, 2013). Apart from shocks due to crises, less extreme business cycle fluctuations may have considerable impact on early childhood well-being. Indeed, even in less extraordinary times, it is common for negative aggregate shocks to be associated with increased infant mortality across the developing world, particularly for girls (Baird et al 2011, Bhalotra, 2010). ${ }^{1}$ A growing number of studies establish a link between malnutrition during early childhood and slower physical growth, delayed motor development, lower IQ, and low educational achievement. Improving health and nutritional status, on the other hand, is frequently associated with improvements in longerterm outcomes, including reduced likelihood of chronic disease, increases in educational attainment, and higher subsequent returns in the labor market. ${ }^{2}$

The Global Financial Crisis of 2008 was not the first macroeconomic event to threaten child nutritional status. Not only have families with young children in middle and lower income countries endured significant macroeconomic shocks in recent years, but governments have responded with efforts to alleviate impacts on vulnerable populations. The Government of Indonesia's policy response to the East Asian financial crisis in 1997-1998 is one such example. ${ }^{3}$ While there is ample evidence that the nutritional status of young children did not decline in Indonesia in the wake of the 1997/98 financial crisis (e.g., Block et al, 2004; Frankenberg et al, 1999; Strauss et al, 2004; Thomas and Frankenberg, 2007), research as to whether specific policies can be credited with helping to avert negative consequences to

\footnotetext{
${ }^{1}$ The counter-cyclical relationship does not hold in all circumstances. Miller and Urdinola (2010) find a procyclical relationship associated with coffee price fluctuations in Columbia, which is driven by a decline in the opportunity cost of providing time to child health maintenance when the price of coffee declines.

2See, for example, Alderman et al 2001; Alderman, Behrman and Hoddinot, 2005; Alderman, Hoddinot and Kinsey 2006; Glewwe, Jacoby and King 2001; Glewwe and King 2001; Maluccio et al 2005; Martorell 1999; and Strauss and Thomas, 1998.
}

3See Friedman and Sturdy (2011) for a review including policy responses in other countries. 
nutritional status is relatively sparse. ${ }^{4}$ By improving our understanding of how Indonesia's policy response affected child nutritional outcomes, this paper aims to offer lessons for policymakers both in Indonesia and in other economies with vulnerable populations.

This study evaluates the effect of a supplementary feeding program implemented between 1998 and 2000, Program Makanan Tambahan (PMT), on child health and nutritional status in Indonesia. The specific aim of the feeding program was to prevent children under five years of age from suffering deterioration in nutritional status as a result of the crisis. Exploiting differences across communities in the timing of program implementation, the study estimates the difference in the effect of an additional month of exposure between age-eligible young children and older children not targeted by the program. The analysis takes advantage of rich information included in two rounds of panel data from the Indonesia Family Life Survey (IFLS-2 and IFLS-3) covering the pre- and post-crisis periods (1997 and 2000, respectively). Crucial to our identification of the "intent-to-treat" effect of the PMT program, the community questionnaire provides detailed information on the implementation of emergency social safety net programs, which allows us to determine the duration of program exposure within the community.

Prior work evaluating public health programs in Indonesia, including the impact of placing midwives in communities (Frankenberg and Thomas, 2001; Frankenberg et al, 2005), recognizes the importance of controlling for program placement. Our identification strategy exploits duration of program exposure for two reasons: First, nearly all communities were treated, but child exposure differed with age and the timing of implementation within villages (desa) and urban communities (kelurahan). Second, the impact of early childhood development

\footnotetext{
${ }^{4} \mathrm{~A}$ range of other work has looked at the impacts of the crisis on educational investments and health care utilization. Thomas et al (2004) and Thomas and Frankenberg (2007) report short and longer-term effects, respectively, of the crisis on education spending and enrollments. Cameron (2009) finds that Indonesia's Social Safety Net Program reduced school drop-out rates, particularly among students in lower secondary school who were historically most at risk of dropping out. Pradhan et al (2007) and Johar (2009) differ considerably over whether a health card program, which was expanded in the wake of the crisis, had any impact on health care utilization.
} 
(ECD) programs tend to vary with the rate of take-up and the cumulative effects of participation over time, both of which are sensitive to duration of program exposure (King and Behrman, 2009). ${ }^{5}$ For these reasons, this paper identifies impacts of the PMT program by exploiting differences in program exposure within communities while controlling for fixed community characteristics across the two survey waves.

At the time of the 2000 survey, most young children under five were exposed to different combinations of treatments depending on their age. Feeding regimens and nutritional content differed for 6-12 month, 12-24 month and 24 to 60 month old children, but regardless of age in 2000, we find that the program had significant impacts on treated children. After controlling for exposure of the mother to nutritional support programs when a child was in utero, we find that 6 months of exposure to the program for children who are 12 months old at the time of the survey reduced the likelihood of severe stunting by 1.2 percentage points, which corresponds to an 8.6 percent reduction in the probability of severe stunting. The effects of the program are cumulative, and are stronger for toddlers and young children with longer exposure. Toddlers (aged 12-24 months) and young children (24-60 months) with 12 months exposure to the PMT program experienced increases of 0.11 and 0.13 standard deviations in standardized height for age, respectively, and 14.8 and 26.8 percent reductions in the probability of severe stunting.

The paper is organized as follows. Section 2 provides discussion of the program and its implementation, and section 3 follows with a brief introduction to the data source, the Indonesia Family Life Survey (IFLS). The analytical framework and empirical strategy are developed in section 4 . Results are presented in section 5 and a final section concludes.

\footnotetext{
${ }^{5}$ Behrman et al (2004), and Gertler (2004) examine ways in which impact of ECD programs vary with program exposure and also exploit duration of exposure in their identification strategies. Frankenberg and Thomas (2001) exploit timing of placement and duration of exposure in examining the impact of village midwife placement on women's health status.
} 


\section{A Nutritional Intervention Aimed at Protecting Young Children}

The goal of the PMT supplementary feeding program was to maintain and to improve the nutritional status of children under five, particularly those at risk as a result of the 1997-98 economic crisis. ${ }^{6}$ The intervention divided children into three subgroups, with the program share of total diet, nutritional composition and the frequency of supplement provision varying by age group. Infants (6-12 months) received soft meals containing 360-430 kcal of energy per 100 grams of food and 10-15 grams of protein, which were to be consumed over three to four feedings during the day for 180 consecutive days. Young toddlers (12-24 months) were provided with up to 90 food supplements that included (360-430 kcal per day) and protein (911 grams per day) over 12 months. Finally, children aged 24-60 months received up to 90 locally prepared snacks with a nutritional composition that included energy $(360-430 \mathrm{kcal})$ and protein (9-11 grams). The difference in the program between these two older groups was substantial: for younger children, the supplementary snack would be consumed daily or every other day for a longer period, while older children received less frequent snacks that were a smaller share of total daily nutrition requirements. ${ }^{7}$

Funding for the PMT was distributed to local public health clinics, the Pusat Kesehatan Masyarakat (Puskesmas), and a list of children eligible to receive supplementary food was then prepared by the village (or urban community) midwife in consultation with other local leaders. Others involved in preparing the program's recipient list may have included the village head or other officials, family planning workers and community activists. As with other community health programs in Indonesia, program supervision was the responsibility of

\footnotetext{
${ }^{6} \mathrm{~A}$ monthly supplementary feeding program existed prior to the crisis as part of a public health program. In contrast to the post-crisis supplementary feeding program, the pre-crisis program did not reach as many children and families, and was being phased out before the crisis hit. Under this program, food supplements were delivered along with basic health services to preschool age children and pregnant women.

7In addition to children under 5, the program also targeted pregnant women, with the objective of reaching women from poorer households. These services included pregnancy monitoring and provision of pregnancy vitamins. In the labeling of age ranges in this paper, a child falls within a specified age range if his (or her) age is greater than or equal to the lower bound and less than the upper bound. For example, aged 6 to 12 months refers to greater or equal to 6 months and less than 12 months.
} 
the village midwife if one was present, and otherwise it was assumed by the Puskesmas. ${ }^{8}$ Descriptive information from the IFLS shows that in 62 percent of IFLS communities, the village (or community) midwife administered the program, and in 35 percent the program was supervised by a member of the Puskesmas staff. Other than working through the Posyandu and village midwives, the village women's association (Program Kesejahteraan Keluarga, PKK) may have also played a role in delivering nutritional supplements to members of the community.

Although developed with the aim of supporting poorer children between 6 and 60 months of age and pregnant women, program implementation followed patterns of policy intervention that were common under the Suharto regime. Central and regional governments first decided which communities would receive the program, and then determined the timing of implementation (hereafter, community includes both rural desa and urban kelurahan). Implementation of the PMT was nearly universal, but poorer communities were targeted first. While the program was intended to help poorer children, it was made available to every age eligible person in the community through the Posyandu. The majority of communities that received the program from 1998 to 2000 provided treatments to all three sub-groups of children. In fewer than four percent of communities, non-targeted individuals received some benefits, including children 5-14 years old, women in reproductive age, the elderly and in some cases, even adult males.

While some communities received the program in 1998, the emphasis on poorer communities and differences in local capacity likely led to differences in the timing of program roll out. Program coverage, as indicated in Table 1, was lower at the beginning of the period (early 1998), due to the fact that the crisis had not been anticipated in the 1997-1998 budget. $^{9}$

\footnotetext{
${ }^{8}$ Village midwives are trained to provide basic health services in communities (both urban kelurahan and rural desa). Their work is coordinated and supervised by the head of the local health clinic (Puskesmas), which typically serves a kecamatan (an administrative area intermediate in size between the district and the village).

${ }^{9}$ The national budget plan (fiscal year) in Indonesia prior to 2001 ran from April 1 to March 31. Since 2001, the Government of Indonesia's fiscal year corresponds to the calendar year.
} 
During the following fiscal year (1998-1999) program coverage expanded to over 70 percent of communities. By 1999-2000 nearly 93 percent of communities were covered before declining to 83 percent during the first half of fiscal year 2000-2001.10 During the 1998-2000 period most of the sampled communities (97.3 percent) were exposed to the program for some period of time.

\section{Evaluation of the PMT Using the Indonesian Family Life Survey}

Features of the Analysis Sample and Health Measures. The data used in this study come from the 1997 and 2000 rounds of the Indonesia Family Life Survey (IFLS), which covers periods before and after the 1997-1998 Asian Financial Crisis and implementation of the child supplementary feeding program. The IFLS is a panel survey that enumerates information on various aspects of individual, household and family livelihoods. In addition, information on characteristics of communities is also collected, including features of the socio-economic environment, physical infrastructure, health and education facilities, and programs administered through these facilities. ${ }^{11}$ In this study we link community-level data on implementation of the supplementary feeding program from 1998 onward with individual-level data on health and nutritional status of children. Information on the PMT program is found in the Safety Nets module of the IFLS 2000 community questionnaire, which was filled out for 303 communities, as opposed to 311 for the basic community module (Strauss et al, 2009). Of these, we exclude three communities in which we do not observe valid height-for-age z-scores for treatment age children.

The analysis sample includes all children who were between 6 and 96 months who lived in IFLS communities at the time of the 1997 and 2000 survey rounds and for whom valid

\footnotetext{
10 Pritchett et al (2002) note that the initial fiscal year 1998-1999 did not provide for broad emergency programs to cope with negative impacts of the crisis. In July 1998 the current budget was revised to include an explicit Social Safety Net Program.

${ }^{11}$ One author of this paper was a member of the IFLS3 survey team. A discussion of sampling and survey methods for IFLS2 and IFLS3 can be found in Frankenberg and Thomas (2000) and Strauss et al (2004), respectively.
} 
measures of height for age z-scores could be calculated (3674 and 3932 children, respectively). Among children in the sample, those aged 60 to 96 months form a control group (1705 and 1626 in 1997 and 2000, respectively) and the remaining 1965 and 2306 are in the younger three age groups that were treated with exposure to one or more of the PMT supplemental feeding programs between 1998 and 2000. Professional training of enumerators and repeated efforts to make contact with all children kept "non-response" due to refusal or inaccuracies in measurement relatively low at an average of 15.4 percent for children of treatment age and 10.6 percent for those in the control group. As these are low but hardly negligible, we assess below whether exclusion of children with invalid height-for-age z-scores might contribute to biased estimates of program impact.

The average age of treatment-age children in 1997 and 2000 was 34.5 and 32.4 months, respectively. Given the low percentage of communities in which non-targeted groups (older children and adults other than pregnant women) received benefits, the share of non-targeted children in the control group who were exposed to the program is likely to be negligible. Nonetheless, we also check the robustness of our results using an additional older control group of children aged 96 to 120 months (1183 and 1133 in 1997 and 2000, respectively).

We focus on height as the health outcome of interest, as opposed to weight or other available measures of child health, because it picks up longer-run investments in nutritional status. Height is most likely to be associated with duration of exposure to the PMT, particularly given that the PMT ended in some communities before the 2000 round of the survey was completed. Further, height captures early-childhood nutritional investments (as well as other health investments) that have been found to have a long-term relationship with cognitive development and important outcomes later in life. Given that our identification exploits differences in duration of program exposure and that the program was no longer present in some of the IFLS communities when the 2000 survey round data were collected, we 
believe that standardized height-for-age is the most relevant child health indicator for us to examine. ${ }^{12}$

To focus on more severe effects, we also examine the probability that children suffer from (moderate) stunting, or $\mathrm{HAZ}<-2$, which is often referred to in the medical literature as shortness, and severe stunting, or HAZ<-3. Standardized height-for-age is calculated using 2006 WHO Child Growth Standards. ${ }^{13}$ As noted above, the WHO macro used to calculate height-for-age z-scores drops estimates less than -6 and greater than 6. Among children of treatment age, we were not able to calculate valid height-for-age z-scores for 159 and 464 children of treatment age (6 to 60 months) in 1997 and 2000, respectively, and for 20 and 250 children of control age (60 to 96 months). ${ }^{14}$ As the excluded shares of children are not negligible, we also explore whether the duration of PMT program exposure experienced by treatment-age children made them more or less likely to be excluded from the analysis sample than control-age children. Whether controlling for community fixed effects or not, we find no evidence that this might be the case. ${ }^{15}$

In Table 2, we show the mean child standardized height-for-age and proportion of children suffering from stunting and severe stunting in 1997 and 2000. Among children between 6 and 60 months of age, we observe an insignificant change in child standardized height-for-age from 1997 to 2000. More striking, however, are the significant reductions in stunting and severe stunting. Specifically, the proportion of children 6-12 and 12-24 months

\footnotetext{
${ }^{12}$ As suggested by a referee, we also examined weight for height z-scores, which pick up important higher frequency variation in nutritional status, but we observed little impact associated with the PMT. As the program had been phased out in many communities by the time of the survey, it is not surprising that we found no measurable impact on weight.

${ }^{13} \mathrm{An}$ earlier version of this paper used the 2000 CDC growth standards. The $2006 \mathrm{WHO}$ standards are based on a more accurate measurement of height for children under two than the CDC standards (de Onis et al, 2006), and thus lead to a lower expected standard deviation in height for age.

${ }^{14}$ We reproduce the "non-response" statistics in Appendix Table A.1. Using the 2000 CDC standards, we note that "non-response" was somewhat higher in both years. Appendix materials are available on-line or in penultimate working paper drafts (World Bank Policy Research Working Paper 5471 and as an IZA Discussion Paper).

${ }^{15}$ For additional details see Appendix Table A.2 and the following discussion.
} 
who suffered from severe stunting decreased from 0.14 to 0.07 and 0.25 to 0.19 , respectively, from 1997 to 2000.

It should be noted that the analysis sample only includes children living in original IFLS communities. Children who had moved with parents to new communities, or were born to parents who had moved, are excluded because the shortened community survey form administered for movers did not include questions about the PMT nutritional supplement program. On average, excluded children in both years tend to have higher height-for-age zscores than included children, and tend to show modest improvement between 1997 and 2000. As the exclusion of the children of movers may be of some concern, we examine whether migration is associated with duration of PMT exposure below.

To isolate the effect of the program on child nutritional status, we also control for biological, socio-economic and demographic characteristics that determine both parental preferences and household permanent income, and thus may be correlated with child nutritional status but unrelated to program exposure. Other than child age and gender, we control for mother and father's height and education, household demographic characteristics, household access to a toilet and sanitation facilities, and additional community characteristics, which are shown in Table 3.

Evidence on Program Placement. In order to motivate our analytic approach, we first investigate differences in program duration across communities with an eye toward assessing the importance of controlling for province, district or community fixed effects. ${ }^{16}$ We use ordinary least squares to examine the correlates of program duration with 1997 community-level covariates, including measures of average child nutritional status, socio-economic status, health and physical infrastructure as well as variables that proxy for remoteness of the community. In alternative models we include province and then district (kabupaten) fixed-

\footnotetext{
${ }^{16}$ Appendix Figure A1 summarizes the community average distributions of height for age, proportion stunted, community average $\ln$ (Per Capita Expenditure) and program duration.
} 
effects to control unobserved heterogeneity that may be associated with the timing of program implementation. Estimation results are shown in Table 4. In the first set of models, with province fixed effects, we include community average height-for-age of children under 60 months in column (1), and share of children stunted in column (2). Neither of the communityaverage child health measures are significant. The F-tests on province fixed effects, 4.37 and 4.41 respectively, establish that there is significant variation in duration across provinces. Communities with asphalt roads were exposed to the program longer than those without, which probably reflects easier roll out in more accessible areas where there are fewer problems with staffing and retention of midwives (Chomitz et al, 1998).

Within district (kabupaten) models are estimated in columns (3) and (4). Notably, the Fstatistics on district fixed effects are higher than on province fixed effects, suggesting considerable and significant within-province variation in duration of exposure. In contrast to models (1) and (2), once we control for district fixed effects, communities with higher average per-capita expenditure are found to have longer exposure to the PMT program. The F-tests on the economic status variables are also significant in models (3) and (4), confirming the importance of community economic status in determining duration of PMT exposure.

If program allocation during 1998-2000 was based entirely on 1997 characteristics as modeled here, the finding that urban communities received treatment for longer would be inconsistent with the fact that average nutritional status in urban communities in 1997 was higher than in rural areas. The allocation procedure may be based on the community characteristics in 1998 and 1999, or changes from 1997, which we cannot observe in the IFLS. It is apparent from this exercise, however, that both observed and unobserved characteristics of communities receiving the program may have influenced program duration. For this reason, we favor models employing community fixed effects. 


\section{Empirical Approach}

Our empirical approach can be motivated by a standard household model (e.g., Rosenzweig and Wolpin, 1986), in which preferences of household $i$ are inter-temporally separable, and we assume that the household maximizes a quasi-concave utility function over goods and services. The production of health (or nutritional status) is a function of per child health inputs, household characteristics, and both observed and unobserved community characteristics. Households maximize utility conditional on a health production function and a budget constraint in which spending cannot exceed household income (or, at least, households face a credit constraint in their spending on goods, services and health inputs).

The impact of providing a public nutrition program can be decomposed into two effects: (1) a subsidy effect that could lead to an increase in demand for nutrition inputs (a price effect); and (2) reallocation of resources within the household, which will have an ambiguous impact on a child targeted by the subsidy. The effect on the eligible child will depend on whether and how much the household reallocates nutritional resources from the treated children to other household members. Estimating the effect of the subsidy is complicated by the likelihood that its introduction and duration of availability is correlated with unobserved characteristics of the household, child or community. The sign of any program placement bias is ambiguous. It will be negative when the government, or implementer of the program, follows a compensatory principle by targeting first (or longest) to less-endowed areas. On the other hand, if the program is placed more intensively in better endowed areas, the sign of the bias may be positive and the estimated program effect will overstate the true effect. Our approach to identification, which exploits community-level duration of exposure, requires an estimation strategy that is plausibly robust to biases associated to program placement. 
Potential Sources of Bias. We are concerned about two potential sources of bias: (1) the measure of community exposure to the PMT nutrition support program may proxy for other programs or such unobservables as village leader initiative; (2) the program may have influenced household decisions, such as those related to in- or out-migration or fertility.

With respect to the first set of concerns, it is important to recognize that the PMT program was not the only safety net or health support program implemented in Indonesia's communities and villages. Since the program was handled either by a village midwife or through the Posyandu (medical clinics under the Puskesmas) one may worry that the effects of the PMT program may be confounded with other public health initiatives operating through these same providers. We do not believe this to be likely, however, because there was a significant decline in other health services provided by the Posyandu over the period from 1997 to 2000. Strauss et al (2004) report that provision of Oralit, an oral rehydration treatment for diarrhea, had decreased 9.4 percent by 2000 and child growth monitoring services were 14.1 percent lower than in 1997. Nonetheless, the community and facility survey information from 1997 and 2000 allows us to examine whether the duration of exposure to the PMT was systematically related to changes in other programs implemented through midwives, the Puskesmas or Posyandu and available in pre- and/or post-crisis years. Such programs included an earlier food supplementation program, provision of oralit, iron supplementation, immunization programs, pre-natal checkups for pregnant women, maternal health programs, and child development services.

In Table 5 below, we show results from a village-level regression examining the correlation of change in availability of each of these types of programs and duration of exposure to the PMT nutrition support program as of the survey date in 2000. Specifically, we regress change in access to each of these programs on duration of the PMT and a set of 1997 village-level covariates likely to influence access to these programs (an urban indicator, indicator for presence of an asphalt main road, availability of piped water in the community, 
presence of a sewage system, distance to the district capital, number of midwives, number of Posyandu). Examining coefficients on duration of exposure, we find no explicit evidence that changes to other programs potentially affecting child health are associated with exposure to the PMT program.

A second source of bias may arise from selective fertility or migration, and this is one reason that Rosenzweig and Wolpin (1986) emphasized the importance of employing child fixed effects when using child exposure to evaluate the impact of a supplementary feeding program. Unlike the Philippine panel used by Rosenzweig and Wolpin, the time between the 1997 and 2000 survey waves is much shorter than the full period of the Philippine panel, and relatively few children would be old enough to appear in 1997 and young enough to receive the 6-12 or 12-24 month treatments through the PMT. Further, those children receiving these treatments by the 2000 survey would be born after the 1997 survey round. ${ }^{17}$

To address concerns over selective fertility responses, we examine the relationship between fertility of women of child-bearing age and months of exposure to the PMT program as of 2000. We estimate two models:

$$
y_{i t}=\alpha y 2000_{t}+\theta P M T_{j 2000}+\boldsymbol{X}_{i t}^{\prime} \boldsymbol{\beta}+u_{j}+\epsilon_{i t}
$$

and

$$
\Delta y_{i t}=\theta P M T_{j 2000}+\boldsymbol{X}^{\prime}{ }_{997} \boldsymbol{\beta}+\varepsilon_{i t}
$$

where $y_{i t}$ and $\Delta y_{i t}$ are the number of children and change in number of children, respectively. In equation (1), $y 2000_{t}$ is a dummy for the 2000 survey round, $P M T_{j 2000}$ is the number of months of exposure to the PMT program in village $j$, and $\boldsymbol{X}_{i t}$ is a vector of individual characteristics in year $t$, including age, age-squared and years of education. In models using

${ }^{17}$ Frankenberg et al. (2005) also point out that interpreting the first difference or FE estimates of standardized height-for-age are complicated by the fact that this measure tends to decline with age until weaning, bounce back slightly, and then remain constant. From this observation, we believe that even where feasible, the fact that child exposure to the PMT may start at slightly different ages could lead to biases in the FE estimator. 
the 1997 and 2000 waves of the IFLS, we include a community fixed effect, $u_{j}$, in one specification. Where we look at change in fertility of woman $i$, in equation (2), we regress change in children on the 1997 values of individual characteristics. We show results examining a possible fertility response in Table 6.A. Whether looking at number of births, with or without community fixed effects, in columns (1) and (2), at number of births using lagged covariates (3), or changes in births, shown in column (4), there is little evidence of a strong fertility response to the PMT program. While the coefficient on program duration is significant at the $10^{\text {th }}$ percentile in models with community fixed effects (column 2), the magnitude implied by the positive coefficient is not sufficiently large to suggest that any fertility-related bias to impacts of the program on nutritional status will be significant. Further, from models of fertility using lagged covariates (column 3) and differences (column 4) there is no evidence that duration of PMT program availability might be associated with increased fertility.

In examining whether the PMT is systematically related to migration decisions, we test whether migration differs for parents who have a child of age to be treated by the program from those parents with at least one child in the control group age range, and whether migration of treatment-age children is associated with duration of exposure to the PMT. Specifically, we control for survey round (y2000), an indicator for a child of treatment age, duration of PMT exposure, and the interaction of these variables, as well as other covariates. A significant coefficient on the y2000-treatment age-PMT duration interaction would suggest that out-migration patterns differ between treatment and control groups, which would be problematic for our identification strategy below.

Whether estimating this model without, or with, community fixed effects, as in columns (1) and (2) of Table 6B, we find no evidence that out-migration of treated children differs substantially from older control children. After looking at whether there are differences across treatment and control age children in year 2000 migration associated with lagged controls (model 3 of Table 6B) and whether there are differences across groups in the change in 
migration (model 4 of Table 6B), we draw further comfort that out-migration does not differ systematically across treatment- and control-age children.

Given the possibility that the crisis led to significant return migration, one might also worry that in-migration may differ significantly across treatment and control groups. Remembering that the IFLS is a panel study, households migrating into the community between the two periods do not appear in the study if they were not part of original IFLS households. Still, there is a possibility that women with young children may return to IFLS households and migrant return patterns may differ significantly between treatment and control groups. The number of return migrants is quite small, 46 of treatment age and 34 of control age, and their height-for-age z-scores and stunting probabilities do not differ significantly from the larger sample. We believe it implausible that in-migration may be biasing the results we present below.

Estimating the Impact of the PMT Program. To estimate impact of the PMT, we exploit differences across villages in exposure to the program and identify the impact on eligible infants and young children relative to children who were somewhat older and ineligible to receive nutrition support under the program. ${ }^{18}$ As 97 percent of villages eventually received the PMT nutritional supplement program, we use months of exposure to the PMT within the village. The analysis sample is comprised of four groups of young children in 1997 and 2000, those aged: 6-12 months, 12-24 months, 24-60 months and 60-96 months. For each cohort of children, we estimate the model:

$$
H A Z_{i v t}=\alpha_{0}+\beta^{j} P M T_{v t}+\mathbf{Z}_{i t}^{\prime} \boldsymbol{\gamma}_{1}+\mathbf{Z}_{h t}^{\prime} \boldsymbol{\gamma}_{2}+\mathbf{Z}_{v t}^{\prime} \boldsymbol{\gamma}_{3}+\delta \mathrm{y} 2000+\boldsymbol{\mu}_{v}+\varepsilon_{i v t}
$$

\footnotetext{
${ }^{18}$ Our 'placebo' analysis is similar, in some respects, to an approach used by Frankenberg et al (2005) to examine the impact of the village midwife program on child health status.
} 
where a child's height for age z-score $\left(H A Z_{i v t}\right)$ is a function of the number of months that the PMT program was in the village, $P M T_{v t}$, time-varying individual, household, and community characteristics, $\mathbf{Z}_{i t}, \mathbf{Z}_{h t}$ and $\mathbf{z}_{v t}$ shown in Table 3. Additional covariates include a dummy for the 2000 survey round, $\mathrm{y} 2000$, community fixed effects, $\boldsymbol{\mu}_{v}$, and an error term. We estimate the intent-to-treat effect of a month of exposure to the PMT program, $\beta^{j}$. As nearly all villages were covered by the PMT, $\hat{\beta}^{j}$, will pick up the effect of an additional month of exposure relative to 1997, before implementation of the program.

While village fixed effects may control for fixed unobservables that affect program placement, timing (and duration of exposure) could be related to time-varying unobservables that are related to other health programs, despite evidence presented in Table 5, or to trends associated with village management and village leader preferences for promoting early childhood nutrition. Because other health, nutrition and child development services did not have age restrictions, the availability of an ineligible older group offers a natural placebo experiment: we identify the effects of exposure to the PMT by comparing effects on treated younger children and older, age-ineligible children. Under this approach, a village leader with an unobservable concern and focus on child health and development will have an effect on administration of programs for all children, but age restrictions on the PMT will mean that only some children benefit from this initiative.

In our estimation, we thus stack models for three groups of treated children -- aged 6$12,12-24$ and 24 to 60 months $(j=1,2,3)$, respectively, and an older control group, aged 60 to 96 months at the time of the survey. These models are estimated using multivariate regression, and the effects of the PMT on height for age z-scores of children of specific age cohorts are calculated by differencing across equations. We first calculate the difference-in-difference parameters, $\beta^{j}-\beta^{\text {control }}$, for $j=1,2,3$. As both the nutrition provided under the program and program administration differed by child age, and we are estimating impacts on child height for age in 2000, the estimates for the two older groups of children reflect the contributions 
from two different nutrition support regimens. Children in the middle group (12 to 24 months of age) may have received both the treatment intended for those aged 6-12 months and for those 12 to 24 months, and younger children in the 24 to 60 month range also likely received a mix of two or even three treatments. In our setup, the treatment for infants can be identified by differencing $\beta^{1}-\beta^{\text {control }}$, combined treatments for those aged 12-24 and 24-60 months are calculated as $\beta^{2}-\beta^{\text {control }}$ and $\beta^{3}-\beta^{\text {control }}$, respectively. Next, we attempt to distinguish effects of the second and third treatments through additional differencing: $\left(\beta^{2}-\beta^{\text {control }}\right)-$ $\left(\beta^{1}-\beta^{\text {control }}\right)$ and $\left(\beta^{3}-\beta^{\text {control }}\right)-\left(\beta^{2}-\beta^{\text {control }}\right){ }^{19}$

\section{Results and Analysis}

In Table 7 we show results of from estimating (3) over the four groups of children. We present the coefficient estimate of the effect of months of exposure to the PMT program on height-for-age $\mathrm{z}$ scores in the first row of Panel A. All other coefficient estimates are suppressed in this and following tables. ${ }^{20}$ The negative and significant coefficient on months of exposure for the control group reflects the fact that program may have been distributed first to communities hit harder by the crisis. The diff-in-diff estimates presented in the second row suggest that an additional month of village-level exposure to the program increased heightfor-age by 0.009 and 0.011 standard deviations for the 12 to 24 and 24 to 60 month age groups, respectively. Recognizing that some children in these groups received a mix of treatments, we next difference across treatment groups. Differencing the coefficient on months of exposure for the 12-24-month treatment group from the coefficient on the 6 to 12-month group suggests that

\footnotetext{
${ }^{19}$ An additional exercise, reviewed in the Appendix, rules out the possibility that results may be driven by an unobserved differences across villages in the trends in health service provision. See Appendix Table A.9 and discussion.

${ }^{20}$ Regressors not shown in Table 7 include: a year dummy, a program dummy, gender, age (a quadratic measured in months), per capita expenditure (ln), parental height, parental education, household demographic variables (male head, number of children, number of female and male adult), community characteristics (distance to bus station, whether main road is asphalt, availability of sewage and piped water).
} 
the second regimen contributed to an increase in the height-for-age z-score of 0.012 standard deviations for each month of exposure.

In interpreting these results, it is useful to remember that there are two ways in which longer village exposure may lead to improved nutritional status. First, eligible children will receive nutritional supplements over a longer period of time, and second, parents may have better knowledge of the program and, once eligible, enroll children more quickly in those villages with longer exposure. Recognizing that most children received treatment for several months, it is useful to consider the implications of estimated treatments for specific durations. With 12 months of treatment, the 12-24 and 24-60 month age groups are 0.108 and 0.132 standard deviations taller, respectively. ${ }^{21}$

From the perspective of preventing serious deleterious effects of malnourishment, we highlight the effects of the program on severe stunting $(H A Z<-3)$ in panel C of Table 7. Each month of village exposure reduces the probability of severe stunting by $0.20,0.31$ and 0.43 percentage points (Panel C, row 2) for the 6-12, 12-24 and 24 to 60 month age groups, respectively. For six months of treatment, this corresponds to a 1.2 percentage point reduction for infants, and 12 months of treatment for the older two groups correspond to 3.7 and 5.1 percentage point reductions. Given severe stunting rates of 14, 25 and 19 percent, respectively, for these age groups in 1997 (Table 2), these effects amount to 8.6, 14.8 and 26.8 percent reductions in the rates of severe stunting.

Although we have shown above that results were unlikely to be biased due to systematic differences in the out-migration of treated and control cohorts, we may yet be concerned about bias due to selective out-migration based on unobservable characteristics that are correlated with the PMT. To examine the extent of this possible bias, we re-estimate the intent-to-treat model including children who migrated with parents, and children born to migrant parents. From these estimates (shown in Appendix Table A.6), we note a decline in

\footnotetext{
${ }^{21}$ Appendix Table A.5 summarizes estimates of program impact on height-for-age z-scores, stunting and severe stunting at different points in the community-level distribution of program exposure.
} 
the magnitude of coefficients on duration of exposure for severe stunting, but differences with those shown in Table 7 are not significant. Estimates of the impact of the 12-24 month treatment on height-for-age z-scores and in reducing moderate stunting remain significant but magnitudes are roughly half those of estimates based exclusively on children remaining in the village. From this exercise we conclude that our main result is not driven by selection on unobservables.

While we establish statistical significance of the PMT program on moderate stunting of children 12-24 months of age and on severe stunting for children between 6 and 60 months of age, it is worth considering whether these findings are economically significant. Using the IFLS 1997 survey round as the base year, our results suggest that the PMT program moved 87 children under 60 months of age, and 18 under 24 months of age, from extreme stunting to stunting. This does not seem like a particularly significant impact. Projecting the impact onto the national population, magnitudes appear more significant. While national health statistics contemporaneous with the program did not distinguish moderate and severe stunting, we may derive a sense of the potential importance of the program by considering how an intervention with PMT impacts would affect children under five in 2007, when moderate and severe stunting rates were 36.8 and 18 percent, respectively. Using the estimated impact on children aged 12-24 months, and with 12 months of exposure associated with 3.5 and 3.7 percent reductions in moderate and severe stunting, respectively, a program of equivalent impact would reduce moderate and severe stunting by 1.3 and 0.67 percentage points, which would be equivalent to moving approximately 93,000 and 26,000 children under 5 out of moderate stunting and from severe stunting to stunting, respectively. This thought experiment suggests that the program had a significant impact, particularly at a time when, as suggested by the IFLS in 1997, moderate and severe stunting rates were considerably higher. Unfortunately, records of fiscal outlays during the period combine all health safety net programs into one expenditure item and do not allow us to assess whether the PMT program 
was an efficient means of reducing malnutrition. Given the lack of explicit targeting within communities, however, we suspect that the PMT nutrition program was a relatively expensive program for the results achieved.

When thinking about these results, it is relevant to consider how the impact of the PMT compares with those of other supplemental feeding programs. A recent review (Bhutta et al, 2013) finds an average effect of supplementary feeding programs on height for age z-scores of 0.22 with a 95 percent confidence interval ranging from 0.01 to 0.43 standard deviations, and no significant effects on stunting. In food insecure populations these results rise modestly to suggest and average increase in height for age z-scores of 0.25 , and modest reductions in stunting. By contrast, our results for increases in the height for age z-score are lower than the average effects found in the literature, but still quite consistent once we consider the fact that intent-to-treat estimates may establish lower bounds as not all age-eligible children were enrolled in the program.

Gender Differences in Impact? So far we have pooled genders in our analysis, and another explanation for lower estimates may be that parents of boys participate more in the program, or alternatively, reallocate more resources away from daughters subsequent to receipt of supplementary food. We show results from estimating models separately for boys and girls in Table A7 of the Appendix. We find some evidence of significant differences between boys and girls in the effects of the 12-24 month treatment on height-for-age z-scores, and on moderate and severe stunting. Impacts on boys aged 12-24 months suggest more pronounced improvements in nutritional status and when impacts on girls of this age are examined separately, there is little evidence of significant improvement. Although these point estimates suggest a larger impact on the nutritional status of boys relative to girls, t-tests indicate that these differences are weakly significant. ${ }^{22}$

22Maccini and Yang (2009) find significant gender differences in long-term impacts of weather shocks. 
Other checks for heterogeneous impacts are worth mention. We do not find significant differences in impacts on children from households in the bottom 40 and top 40 percent of the 1997 per capita expenditure distribution, and further, we found no significant difference in the impact of the PMT program between urban and rural areas. Finally, while we view height as the most interesting long-term measure of nutritional status in this study, we found no systematic effect of the program on weight for height or wasting.

Are Estimated Impacts Sensitive to Growth Charts Used? An earlier version of the paper used the 2000 US CDC growth charts, and one reasonable critique had been that the 2000 CDC growth charts may not be as representative of young children internationally as the 2006 WHO growth standards. While results of our analysis using the two sets of growth standards are broadly consistent, there are some differences. Most notably, results using the 2000 CDC Growth Charts show no impact of the PMT program on infants aged 6-12 months, and suggest that the most pronounced effect of the program was on children aged 12 to 24 months. Further, significant impacts of the PMT are evident for both moderate and severe stunting using the WHO standards, but observed for moderate stunting (HAZ<-2) using the 2000 CDC curves. This difference is likely driven by the fact that there is tighter variability in the WHO length for age standard at younger ages and the fact that "children in the WHO standard are, on average, taller than those in the CDC chart." 23 All results of our analyses using the 2000 CDC curves are available in Appendix Tables A10 to A14.

\section{Summary and Conclusions}

At the onset of the 1997/1998 East Asian Financial Crisis, disruptions to earnings threatened the health and nutritional status of young children, who already faced malnutrition rates comparable to those observed in Sub-Saharan Africa (Strauss et al, 2004). Failure to

\footnotetext{
${ }^{23}$ de Onis et al (2007) note that the CDC used datasets from several years with no standardization of measurements across them, and thus the CDC standards were prone to have an artificially inflated variability.
} 
prevent increases in malnutrition for infants and young children in the wake of the crisis may have had significant consequences for the cognitive development and later life productivity of a significant share of infants and young children born in the post crisis period. Against this backdrop the PMT nutrition support program can be judged a success.

The relatively modest program effect for HAZ may be related to lack of take up among families with children who were most in need. Qualitative case studies discussing implementation of the PMT have highlighted problems with both program implementation and less than full take up among eligible children (Handayani et al, 2008). A better designed and well-targeted nutritional intervention program may have stronger effects, and further, in consideration of potential differences in either take-up or reallocation behavior among parents with sons and daughters, these programs might explicitly consider ways of raising the nutritional standards of young girls.

\section{References}

Alderman, H., J. Behrman, V. Lavy and R. Menon. 2001. "Child Health and School Enrollment: A Longitudinal Analysis," Journal of Human Resources, 36/1: 185-205.

Alderman, H., J. Behrman and J. Hoddinott. 2005. "Nutrition, Malnutrition, and Economic Growth," Health and Economic Growth: Findings and Policy Implications, Cambridge and London: MIT Press (2005): 169-94.

Alderman, H., J. Hoddinot, and B. Kinsey. 2006. “Long Term Consequences of Early Childhood Malnutrition," Oxford Economic Papers, 58, 450-474.

Baird, Sarah, Jed Friedman and Norbert Schady. 2011. "Aggregate Income Shocks and Infant Mortality in the Developing World," The Review of Economics and Statistics, 93(3): 847-856.

Bhalotra, Sonia R. 2010. "Fatal Fluctuations? Cyclicality in Infant Mortality in India," Journal of Development Economics 93 (1): 7-19.

Behrman, J., Y. Cheng, and P.E. Todd. 2004. "Evaluating Preschool Programs When Length of Exposure to the Program Varies: A Nonparametric Approach," Review of Economics and Statistics, 86(1): 108-132.

Bhutta, Zulfiqar A., Jai K Das, Arjumand Rizvi, Michelle F Gaffey, Neff Walker, Susan Horton, Patrick Webb, Anna Lartey, Robert E Black et al. 2013. “Evidence-Based Interventions for 
Improvement of Maternal and Child Nutrition: What Can be Done and at What Cost? The Lancet 382(9890) (3-9 August 2013): 452-477.

Block, S.A., L. Kiess, P. Webb, S. Kosen, R. Moench-Pfanner, M.W. Bloem and C.P. Timmer. 2004. "Macro shocks and micro outcomes: child nutrition during Indonesia's crisis," Economics \& Human Biology, 2(1): 21-44.

Cameron, Lisa. 2009. “Can a Public Scholarship Program Successfully Reduce School DropOuts in a Time of Crisis? Evidence from Indonesia," Economics of Education Review 28: 308317.

Chomitz, Kenneth, Gunawan Setiadi, Azrul Azwar, Nusye Ismail and Widiyarti. 1998. "What do Doctors Want? Developing Incentives for Doctors to Serve in Indonesia's Rural and Remote Areas," The World Bank, Policy Research Working Paper 1888.

de Onis, Mercedes, Cutberto Garza, Adelheid W. Onyango and Elain Borghi. 2007.

"Comparison of the WHO Child Growth Standards and the CDC 2000 Growth Charts," The Journal of Nutrition, January, 137:144-148.

Frankenberg, E. and D. Thomas. 2000. The Indonesia Family Life Survey (IFLS): Study Design and Results from Waves 1 and 2. March, RAND, Santa Monica, CA. DRU-2238/1-NIA/NICHD.

Frankenberg, E. and D. Thomas. 2001. “Women's Health and Pregnancy Outcomes: Do Services Make a Difference?," Demography, 38: 253-66.

Frankenberg, E., D. Thomas and K. Beegle. 1999. “The Real Cost of Indonesia's Economic Crisis: Preliminary Findings from the Indonesia Family Life Surveys," Labor and Population Program Working Papers Series 99-04, RAND, Santa-Monica.

Frankenberg, E., W. Suriastini, and D. Thomas. 2005. "Can Expanding Access to Basic Healthcare Improve Children's Health Status? Lessons from Indonesia's Midwife in the Village Program," Population Studies, 59(1): 5-19.

Friedman, Jed and Norbert Schady. 2013. "How Many More Infants Are Likely to Die in Africa as a Result of the Global Financial Crisis?" Health Economics 22(5): 611-622.

Friedman, Jed and Jennifer Sturdy. 2011. "The Influence of Economic Crisis on Early Childhood Development: A Review of Pathways and Measured Impact" in No Small Matter: The Impact of Poverty, Shocks, and Human Capital Investments in Early Childhood Development (Harold Alderman, editor). Washington: The World Bank Press: 51-83.

Gertler, P. 2004. “Do Conditional Cash Transfers Improve Child Health? Evidence from PROGRESSA's Control Randomized Experiment," American Economic Review, 94(2): 336341.

Gertler, P., and J.W. Molyneaux. 1994. "How Economic Development and Family Planning Programs Combined to Reduce Indonesian Fertility," Demography, 31(1): 33-63.

Glewwe, P., and E. King. 2001. "The Impact of Early Childhood Nutritional Status on Cognitive Development: Does the Timing of Malnutrition Matter?" The World Bank Economic Review, 15(1): 81-113.

Glewwe, P., Jacoby, H. and E. King. 2001. "Early Childhood Nutrition and Academic Achievement: A Longitudinal Analysis," Journal of Public Economics, 81:345-68. 
Handayani, L., SA Mulasari, N. Nurdianis, 2008. “Evaluasi Program Pemberian Makanan Tambahan Anak Balita," Jurnal Manajemen Pelayanan Kesehatan, 11:1/March.

Johar, Meliyanni. 2009. “The Impact of the Indonesian Health Card Program: A Matching Estimator Approach," Journal of Health Economics, 28(1): 35-53.

King, E. and J. R. Behrman. 2009. “Timing and Duration of Exposure in Evaluations of Social Programs," World Bank Research Observer, 24(1): 55-82.

Linnemayr, S. and H. Alderman. 2011. "Almost Random: Evaluating a Large-Scale Randomized Nutrition Program in the Presence of Crossover," Journal of Development Economics, 96(1): 106-114.

Maccini, Sharon and Dean Yang. 2009. "Under the Weather: Health, Schooling, and Economic Consequences of Early-Life Rainfall," American Economic Review, 99:3, 1006-1026.

Maluccio, J.A., J. Hoddinott, J.R. Behrman, R. Martorell, A. R. Quisumbing, and A.D. Stein. 2009. "The Impact of an Experimental Nutritional Intervention in Childhood on Education among Guatemalan Adults," The Economic Journal, 119(573): 734-763.

Martorell, R. 1999. "The Nature of Child Malnutrition and Its Long-Term Implications," Food and Nutrition Bulletin 20: 288-292.

Miller, Grant and Urdinola, B.P. 2010. "Cyclicality, Mortality, and the Value of Time: The Case of Coffee Price Fluctuations and Child Survival in Colombia," Journal of Political Economy 118(1): 113-155.

Pradhan, Menno, Fadia Saadah and Robert Sparrow. 2007. “Did the Health Card Program Ensure Access to Medical Care for the Poor during Indonesia's Economic Crisis?" World Bank Economic Review 21(1): 125-150.

Pritchett, Lant, Sudarno Sumarto and Asep Suryahadi. 2002. "Targeted Program in Economic Crisis: Empirical Findings from the Experience of Indonesia," SMERU Working Paper.

Rosenzweig, M. and K. Wolpin. 1986. "Evaluating the effects of optimally distributed public programs," American Economic Review, 76:470-482.

Strauss, J. and D. Thomas. 1998. "Health, Nutrition, and Economic Development," Journal of Economic Literature, 36: 766-817.

Strauss, J. F. Witoelar, B. Sikoki, A.M. Wattie. 2009. "The Fourth Wave of the Indonesia Family Life Survey: Overview and Field Report Vol. 1," RAND Labor and Population Working Paper.

Strauss, J., K. Beegle, A. Dwiyanto, Y. Herawati, D. Pattinasarany, E. Satriawan, B. Sikoki, Sukamdi, F. Witoelar. 2004. Indonesian Living Standard Before and After the Financial Crisis: Evidence from Indonesia Family Life Survey, ISEAS, Singapore.

Thomas, Duncan, Kathleen Beegle, Elizabeth Frankenberg, Bondan Sikoki, John Strauss and Graciela Teruel. 2004. “Education in a Crisis," Journal of Development Economics 74: 53-85.

Thomas, Duncan and Elizabeth Frankenberg. 2007. "Household Responses to the Financial Crisis in Indonesia: Longitudinal Evidence on Poverty, Resources and Well-Being," in 
Globalization and Poverty, Ann Harrison (editor) for National Bureau of Economics. Chicago: University of Chicago Press. 
Table 1

Distribution of PMT Coverage Across Communities, 1998-2000

\begin{tabular}{|c|c|c|c|}
\hline & Total & Urban & Rural \\
\hline Communities with PMT from 1998-2000 (\%) & 97.3 & 99.4 & 94.1 \\
\hline 1998/1999 fiscal year (\%) & 71.0 & 74.0 & 66.4 \\
\hline 1999/2000 fiscal year (\%) & 92.7 & 97.2 & 85.7 \\
\hline 2000 fiscal year* (\%) & 82.7 & 83.6 & 81.5 \\
\hline $\begin{array}{l}\text { Number of Communities (Urban kelurahan and } \\
\text { Rural desa) }\end{array}$ & 300 & 181 & 119 \\
\hline \multicolumn{4}{|c|}{$\begin{array}{l}\text { Note: We include the } 300 \text { communities out of } 303 \text { of original urban kelurahan and rural desa in } \\
\text { which Social Safety nets modules included in the } 2000 \text { IFLS community questionnaire were } \\
\text { completed. Three communities were excluded because there were no children in the treatment } \\
\text { group with valid height for age z-scores (HAZs) after applying the } 2006 \text { WHO anthropometric } \\
\text { macro. (Under the WHO standard, children are dropped if their HAZ is calculated to be less } \\
\text { than - } 6 \text { or greater than } 6 .\left(^{*}\right) \text { indicates the fiscal year ended in December. If using the CDC } \\
\text { growth standards, these same three communities would be dropped from the sample. }\end{array}$} \\
\hline
\end{tabular}


Table 2

Standardized Height-for-Age and Incidence of Stunting: Children between 6 and 60 months in $1997 \& 2000$

\begin{tabular}{|c|c|c|c|}
\hline & 1997 & 2000 & Diff \\
\hline \multicolumn{4}{|l|}{ 6-12 Months } \\
\hline Heigh-for-Age (HAZ) & $\begin{array}{l}-0.93 \\
(0.13)\end{array}$ & $\begin{array}{l}-0.98 \\
(0.09)\end{array}$ & $\begin{array}{l}-0.05 \\
(0.15)\end{array}$ \\
\hline Moderate Stunting $(\mathrm{HAZ}<-2)$ & $\begin{array}{c}0.28 \\
(0.03)\end{array}$ & $\begin{array}{c}0.22 \\
(0.02)\end{array}$ & $\begin{array}{l}-0.06 \\
(0.04)\end{array}$ \\
\hline Severe Stunting (HAZ<-3) & $\begin{array}{c}0.14 \\
(0.03)\end{array}$ & $\begin{array}{c}0.07 \\
(0.02)\end{array}$ & $\begin{array}{c}-0.07^{* *} \\
(0.03)\end{array}$ \\
\hline Observations & 183 & 294 & \\
\hline \multicolumn{4}{|l|}{ 12-24 Months } \\
\hline Heigh-for-Age (HAZ) & $\begin{array}{l}-1.90 \\
(0.08)\end{array}$ & $\begin{array}{l}-1.75 \\
(0.07)\end{array}$ & $\begin{array}{c}0.15 \\
(0.11)\end{array}$ \\
\hline Moderate Stunting $(\mathrm{HAZ}<-2)$ & $\begin{array}{c}0.52 \\
(0.02)\end{array}$ & $\begin{array}{c}0.47 \\
(0.02)\end{array}$ & $\begin{array}{l}-0.05 \\
(0.03)\end{array}$ \\
\hline Severe Stunting $(\mathrm{HAZ}<-3)$ & $\begin{array}{c}0.25 \\
(0.02)\end{array}$ & $\begin{array}{c}0.19 \\
(0.02)\end{array}$ & $\begin{array}{c}-0.06^{* *} \\
(0.03)\end{array}$ \\
\hline Observations & 420 & 504 & \\
\hline \multicolumn{4}{|l|}{ 24-60 months } \\
\hline Heigh-for-Age (HAZ) & $\begin{array}{l}-1.91 \\
(0.04)\end{array}$ & $\begin{array}{l}-1.89 \\
(0.03)\end{array}$ & $\begin{array}{c}0.02 \\
(0.05)\end{array}$ \\
\hline Moderate Stunting $(\mathrm{HAZ}<-2)$ & $\begin{array}{c}0.50 \\
(0.01)\end{array}$ & $\begin{array}{c}0.48 \\
(0.01)\end{array}$ & $\begin{array}{l}-0.02 \\
(0.02)\end{array}$ \\
\hline Severe Stunting (HAZ<-3) & $\begin{array}{c}0.19 \\
(0.01)\end{array}$ & $\begin{array}{c}0.18 \\
(0.01)\end{array}$ & $\begin{array}{l}-0.01 \\
(0.01)\end{array}$ \\
\hline Observations & 1362 & 1508 & \\
\hline 60-96 Months & & & \\
\hline Heigh-for-Age (HAZ) & $\begin{array}{l}-1.78 \\
(0.03)\end{array}$ & $\begin{array}{l}-1.73 \\
(0.03)\end{array}$ & $\begin{array}{c}0.05 \\
(0.04)\end{array}$ \\
\hline Moderate Stunting $(\mathrm{HAZ}<-2)$ & $\begin{array}{c}0.42 \\
(0.01)\end{array}$ & $\begin{array}{c}0.40 \\
(0.01)\end{array}$ & $\begin{array}{l}-0.02 \\
(0.02)\end{array}$ \\
\hline Severe Stunting $(\mathrm{HAZ}<-3)$ & $\begin{array}{c}0.13 \\
(0.01)\end{array}$ & $\begin{array}{c}0.11 \\
(0.01)\end{array}$ & $\begin{array}{l}-0.02^{*} \\
(0.01)\end{array}$ \\
\hline Observations & 1709 & 1626 & \\
\hline
\end{tabular}

Notes: Calculated from IFLS data. The total sample $(\mathrm{N}=7606)$ includes all children aged between 6-96 months who reside within the 300 original IFLS communities that received some treatment from the PMT nutritional support program, and for whom the WHO anthropometric macro returned height-for-age z-scores between -6 and 6 . Standard errors are in parentheses. $\left({ }^{*}\right)$ is significant at $\left.10 \% ;{ }^{(* *}\right)$ is significant at $5 \% ;\left({ }^{* * *}\right)$ is significant at $1 \%$. 
Table 3

Descriptive Statistics

\begin{tabular}{|c|c|c|}
\hline & $\begin{array}{l}\text { Mean } 1997 \\
\text { (Std. Dev.) }\end{array}$ & $\begin{array}{l}\text { Mean } 2000 \\
\text { (Std. Dev.) }\end{array}$ \\
\hline \multicolumn{3}{|l|}{ Household } \\
\hline Mother's education & $\begin{array}{c}6.06 \\
(4.04)\end{array}$ & $\begin{array}{c}6.80 \\
(4.02)\end{array}$ \\
\hline Father's education & $\begin{array}{c}6.80 \\
(4.14)\end{array}$ & $\begin{array}{c}7.44 \\
(4.08)\end{array}$ \\
\hline Mother's height & $\begin{array}{l}150.32 \\
(5.01)\end{array}$ & $\begin{array}{l}150.44 \\
(5.07)\end{array}$ \\
\hline Father's height & $\begin{array}{l}161.30 \\
(5.04)\end{array}$ & $\begin{array}{l}161.74 \\
(5.40)\end{array}$ \\
\hline Mother's presence (yes=1) & $\begin{array}{c}0.93 \\
(0.26)\end{array}$ & $\begin{array}{c}0.96 \\
(0.19)\end{array}$ \\
\hline Father's presence (yes $=1$ ) & $\begin{array}{c}0.85 \\
(0.36)\end{array}$ & $\begin{array}{c}0.89 \\
(0.31)\end{array}$ \\
\hline Gender of HH head (male=1) & $\begin{array}{c}0.89 \\
(0.31)\end{array}$ & $\begin{array}{c}0.88 \\
(0.33)\end{array}$ \\
\hline \# of children 6-14 yo in $\mathrm{HH}$ & $\begin{array}{c}1.44 \\
(1.14)\end{array}$ & $\begin{array}{c}1.25 \\
(1.13)\end{array}$ \\
\hline \# of male adult $15-59$ yo in $\mathrm{HH}$ & $\begin{array}{c}1.34 \\
(0.84)\end{array}$ & $\begin{array}{l}1.36 \\
(0.91)\end{array}$ \\
\hline \# of female adult $15-59$ yo in $\mathrm{HH}$ & $\begin{array}{c}1.49 \\
(0.80)\end{array}$ & $\begin{array}{l}1.49 \\
(0.82)\end{array}$ \\
\hline Per-capita expenditure (ln) & $\begin{array}{l}11.93 \\
(0.75)\end{array}$ & $\begin{array}{l}11.89 \\
(0.69)\end{array}$ \\
\hline Community & & \\
\hline Average program exposure (months) & $\begin{array}{l}- \\
-\end{array}$ & $\begin{array}{c}3.99 \\
(6.13)\end{array}$ \\
\hline 6-12 months treatment & $\begin{array}{l}- \\
-\end{array}$ & $\begin{array}{c}6.07 \\
(6.20)\end{array}$ \\
\hline 12-24 month treatment & $\begin{array}{l}- \\
-\end{array}$ & $\begin{array}{c}6.78 \\
(5.95)\end{array}$ \\
\hline 24-60 months treatment & $\begin{array}{l}- \\
-\end{array}$ & $\begin{array}{c}6.12 \\
(6.41)\end{array}$ \\
\hline Distance of comm. to bus station (km) & $\begin{array}{c}4.66 \\
(6.77)\end{array}$ & $\begin{array}{c}3.43 \\
(6.11)\end{array}$ \\
\hline Asphalt road in the comm (Yes=1) & $\begin{array}{c}0.73 \\
(0.44)\end{array}$ & $\begin{array}{c}0.78 \\
(0.41)\end{array}$ \\
\hline Village has sewerage (Yes=1) & $\begin{array}{c}0.55 \\
(0.50)\end{array}$ & $\begin{array}{c}0.51 \\
(0.50)\end{array}$ \\
\hline Village has piped water (Yes=1) & $\begin{array}{c}0.55 \\
(0.50)\end{array}$ & $\begin{array}{c}0.55 \\
(0.50)\end{array}$ \\
\hline \# of Observations & 3674 & 3932 \\
\hline
\end{tabular}


Table 4

Determinants of Program Duration, 1997-2000

\begin{tabular}{|c|c|c|c|c|}
\hline $\begin{array}{l}\text { Model } \\
\text { (Dependent Variable: Months in Community) }\end{array}$ & (1) & (2) & (3) & $(4)$ \\
\hline \multicolumn{5}{|l|}{ Health Status } \\
\hline Average Height-for-Age & $\begin{array}{c}0.434 \\
(0.489)\end{array}$ & & $\begin{array}{l}0.335 \\
(0.524)\end{array}$ & - \\
\hline Proportion of Children Stunted (\%) & & $\begin{array}{l}-1.652 \\
(1.408)\end{array}$ & - & $\begin{array}{l}-2.066 \\
(1.656)\end{array}$ \\
\hline \multicolumn{5}{|l|}{ Sociol-Economic Status } \\
\hline Average Per-Capita Expenditure & $\begin{array}{l}-0.818 \\
(0.643)\end{array}$ & $\begin{array}{l}-0.842 \\
(0.643)\end{array}$ & $\begin{array}{c}-1.746^{* *} \\
(0.706)\end{array}$ & $\begin{array}{l}-1.887^{* *} \\
(0.745)\end{array}$ \\
\hline Share of Households with Male Head (\%) & $\begin{array}{l}1.126 \\
(1.551)\end{array}$ & $\begin{array}{l}1.260 \\
(1.539)\end{array}$ & $\begin{array}{l}1.465 \\
(1.920)\end{array}$ & $\begin{array}{l}1.658 \\
(1.938)\end{array}$ \\
\hline Farm Household Share (\%) & $\begin{array}{c}0.479 \\
(1.235)\end{array}$ & $\begin{array}{c}0.496 \\
(1.236)\end{array}$ & $\begin{array}{l}-1.487 \\
(1.844)\end{array}$ & $\begin{array}{l}-1.395 \\
(1.827)\end{array}$ \\
\hline \multicolumn{5}{|l|}{ Physical Infrastructure } \\
\hline Availability of Asphalt Road (Yes=1) & $\begin{array}{l}1.318^{*} \\
(0.713)\end{array}$ & $\begin{array}{l}1.317^{*} \\
(0.715)\end{array}$ & $\begin{array}{c}0.669 \\
(1.088)\end{array}$ & $\begin{array}{c}0.628 \\
(1.084)\end{array}$ \\
\hline Proportion of Land with Semi-Tech Irrigation (\%) & $\begin{array}{l}-0.817 \\
(1.723)\end{array}$ & $\begin{array}{l}-0.855 \\
(1.707)\end{array}$ & $\begin{array}{l}-0.351 \\
(2.521)\end{array}$ & $\begin{array}{l}-0.537 \\
(2.472)\end{array}$ \\
\hline Access to sewerage system (yes $=1$ ) & $\begin{array}{l}-0.523 \\
(0.606)\end{array}$ & $\begin{array}{l}-0.524 \\
(0.611)\end{array}$ & $\begin{array}{l}-0.057 \\
(0.805)\end{array}$ & $\begin{array}{l}-0.091 \\
(0.808)\end{array}$ \\
\hline Access to piped water (yes $=1$ ) & $\begin{array}{l}-1.513^{*} \\
(0.883)\end{array}$ & $\begin{array}{l}-1.513^{*} \\
(0.876)\end{array}$ & $\begin{array}{c}0.009 \\
(0.955)\end{array}$ & $\begin{array}{l}-0.067 \\
(0.949)\end{array}$ \\
\hline \multicolumn{5}{|l|}{ Remoteness of Community } \\
\hline Distance to District Capital (km) & $\begin{array}{c}0.004 \\
(0.009)\end{array}$ & $\begin{array}{c}0.005 \\
(0.009)\end{array}$ & $\begin{array}{c}0.031 \\
(0.022)\end{array}$ & $\begin{array}{c}0.030 \\
(0.022)\end{array}$ \\
\hline Distance to Bus Station (km) & $\begin{array}{l}-0.110^{*} \\
(0.058)\end{array}$ & $\begin{array}{l}-0.110^{*} \\
(0.058)\end{array}$ & $\begin{array}{l}-0.023 \\
(0.073)\end{array}$ & $\begin{array}{l}-0.023 \\
(0.073)\end{array}$ \\
\hline Public Transportation in Community (Yes=1) & $\begin{array}{c}0.272 \\
(0.748)\end{array}$ & $\begin{array}{c}0.215 \\
(0.761)\end{array}$ & $\begin{array}{l}-0.428 \\
(0.698)\end{array}$ & $\begin{array}{l}-0.450 \\
(0.705)\end{array}$ \\
\hline Urban Community (Yes=1) & $\begin{array}{c}1.158 \\
(0.899)\end{array}$ & $\begin{array}{c}1.138 \\
(0.891)\end{array}$ & $\begin{array}{c}0.356 \\
(1.067)\end{array}$ & $\begin{array}{c}0.406 \\
(1.075)\end{array}$ \\
\hline Fixed-Effects & Province & Province & District & District \\
\hline $\begin{array}{l}\text { R-Squared } \\
\text { F-Test }\end{array}$ & 0.170 & 0.172 & 0.686 & 0.688 \\
\hline Economic status & $\begin{array}{c}0.84 \\
{[473]}\end{array}$ & $\begin{array}{c}0.94 \\
{[0.424]}\end{array}$ & $\begin{array}{c}2.70 \\
{[0.046]}\end{array}$ & $\begin{array}{c}2.72 \\
{[0.045]}\end{array}$ \\
\hline Infrastructure & $\begin{array}{c}1.71 \\
{[0.148]}\end{array}$ & $\begin{array}{c}1.73 \\
{[0.144]}\end{array}$ & $\begin{array}{c}0.10 \\
{[0.981]}\end{array}$ & $\begin{array}{c}0.09 \\
{[0.985]}\end{array}$ \\
\hline Remoteness of community & $\begin{array}{c}1.12 \\
{[0.348]}\end{array}$ & $\begin{array}{c}1.13 \\
{[0.343]}\end{array}$ & $\begin{array}{c}0.65 \\
{[0.628]}\end{array}$ & $\begin{array}{c}0.64 \\
{[0.633]}\end{array}$ \\
\hline Fixed-effect (district/province) & $\begin{array}{c}3.15 \\
{[0.000]}\end{array}$ & $\begin{array}{c}2.88 \\
{[0.001]}\end{array}$ & $\begin{array}{c}38.04 \\
{[0.000]}\end{array}$ & $\begin{array}{l}535.27 \\
{[0.000]}\end{array}$ \\
\hline
\end{tabular}

Notes: $\mathrm{N}=300$. Dependent variable is number of months the program was in the community from 19982000. Independent variables are community averages of 1997 covariates. Robust standard errors are in parentheses. $\left({ }^{*}\right),\left({ }^{* *}\right)$ and $\left({ }^{* * *}\right)$ indicate significance respectively at $10 \%, 5 \%$ and $1 \%$. For F-statistics, the pvalue is presented in brackets under the value. 
Table 5

Is Duration of PMT Exposure Systematically Related to Change in Other Programs?

\begin{tabular}{|c|c|c|c|c|c|c|c|}
\hline Regressors & Food Supp. & Oralit & $\begin{array}{l}\text { Immun- } \\
\text { ization }\end{array}$ & $\begin{array}{l}\text { Pregnancy } \\
\text { Check }\end{array}$ & Iron Supp. & $\begin{array}{l}\text { Child } \\
\text { Dev } \\
\text { Service }\end{array}$ & $\begin{array}{l}\text { Mother \& } \\
\text { Child Health }\end{array}$ \\
\hline $\begin{array}{l}\text { PMT Duration } \\
\text { (months) }\end{array}$ & $\begin{array}{c}0.001 \\
(0.002)\end{array}$ & $\begin{array}{l}0.0001 \\
(0.006)\end{array}$ & $\begin{array}{l}-0.002 \\
(0.003)\end{array}$ & $\begin{array}{c}0.001 \\
(0.008)\end{array}$ & $\begin{array}{l}-0.005 \\
(0.006)\end{array}$ & $\begin{array}{l}-0.009 \\
(0.007)\end{array}$ & $\begin{array}{l}-0.003 \\
(0.006)\end{array}$ \\
\hline Urban (Yes=1) & $\begin{array}{l}0.055^{* *} \\
(0.028)\end{array}$ & $\begin{array}{l}-0.034 \\
(0.062)\end{array}$ & $\begin{array}{c}0.040 \\
(0.038)\end{array}$ & $\begin{array}{l}-0.058 \\
(0.099)\end{array}$ & $\begin{array}{c}-0.157^{* *} \\
(0.069)\end{array}$ & $\begin{array}{c}0.009 \\
(0.108)\end{array}$ & $\begin{array}{l}-0.009 \\
(0.104)\end{array}$ \\
\hline $\begin{array}{l}\text { Main Road Asphalt } \\
(\text { Yes=1) }\end{array}$ & $\begin{array}{l}-0.046 \\
(0.039)\end{array}$ & $\begin{array}{l}0.056 \\
(0.045)\end{array}$ & $\begin{array}{c}0.062 \\
(0.055)\end{array}$ & $\begin{array}{l}-0.016 \\
(0.083)\end{array}$ & $\begin{array}{c}0.104 \\
(0.068)\end{array}$ & $\begin{array}{c}0.079 \\
(0.102)\end{array}$ & $\begin{array}{c}0.127 \\
(0.097)\end{array}$ \\
\hline $\begin{array}{l}\text { Prop. of Semi-Tech } \\
\text { Irrigation Land (\%) }\end{array}$ & $\begin{array}{c}0.004 \\
(0.082)\end{array}$ & $\begin{array}{l}-0.180 \\
(0.120)\end{array}$ & $\begin{array}{c}0.029 \\
(0.074)\end{array}$ & $\begin{array}{l}-0.023 \\
(0.180)\end{array}$ & $\begin{array}{l}-0.174 \\
(0.150)\end{array}$ & $\begin{array}{l}-0.055 \\
(0.194)\end{array}$ & $\begin{array}{c}0.090 \\
(0.213)\end{array}$ \\
\hline $\begin{array}{l}\text { Piped Water in } \\
\text { Community (Yes=1) }\end{array}$ & $\begin{array}{l}-0.017 \\
(0.025)\end{array}$ & $\begin{array}{l}-0.052 \\
(0.058)\end{array}$ & $\begin{array}{c}0.002 \\
(0.043)\end{array}$ & $\begin{array}{c}0.077 \\
(0.089)\end{array}$ & $\begin{array}{c}0.114 \\
(0.073)\end{array}$ & $\begin{array}{c}0.060 \\
(0.102)\end{array}$ & $\begin{array}{l}-0.031 \\
(0.084)\end{array}$ \\
\hline $\begin{array}{l}\text { Sewage System in } \\
\text { Community }(Y e s=1)\end{array}$ & $\begin{array}{l}-0.012 \\
(0.023)\end{array}$ & $\begin{array}{l}0.090^{* *} \\
(0.038)\end{array}$ & $\begin{array}{l}-0.027 \\
(0.041)\end{array}$ & $\begin{array}{l}-0.035 \\
(0.077)\end{array}$ & $\begin{array}{c}0.021 \\
(0.052)\end{array}$ & $\begin{array}{c}0.006 \\
(0.083)\end{array}$ & $\begin{array}{l}-0.027 \\
(0.075)\end{array}$ \\
\hline Distance to District & $\begin{array}{l}-0.000 \\
(0.000)\end{array}$ & $\begin{array}{c}0.001 \\
(0.001)\end{array}$ & $\begin{array}{c}0.001 \\
(0.001)\end{array}$ & $\begin{array}{c}0.000 \\
(0.002)\end{array}$ & $\begin{array}{c}0.001 \\
(0.001)\end{array}$ & $\begin{array}{c}0.000 \\
(0.001)\end{array}$ & $\begin{array}{c}0.000 \\
(0.001)\end{array}$ \\
\hline Number of Midwives & $\begin{array}{c}0.003 \\
(0.005)\end{array}$ & $\begin{array}{c}0.001 \\
(0.006)\end{array}$ & $\begin{array}{c}0.005 \\
(0.006)\end{array}$ & $\begin{array}{l}-0.023 \\
(0.022)\end{array}$ & $\begin{array}{l}-0.021 \\
(0.019)\end{array}$ & $\begin{array}{l}0.039^{*} \\
(0.021)\end{array}$ & $\begin{array}{l}-0.029 \\
(0.022)\end{array}$ \\
\hline Number of Posyandu & $\begin{array}{c}0.000 \\
(0.001)\end{array}$ & $\begin{array}{c}0.002 \\
(0.003)\end{array}$ & $\begin{array}{c}-0.002 \\
(0.003)\end{array}$ & $\begin{array}{l}-0.007 \\
(0.006)\end{array}$ & $\begin{array}{c}-0.001 \\
(0.003)\end{array}$ & $\begin{array}{l}-0.000 \\
(0.006)\end{array}$ & $\begin{array}{c}-0.000 \\
(0.004)\end{array}$ \\
\hline Constant & $\begin{array}{c}0.015 \\
(0.040)\end{array}$ & $\begin{array}{l}-0.068 \\
(0.053)\end{array}$ & $\begin{array}{c}-0.052 \\
(0.071)\end{array}$ & $\begin{array}{c}0.094 \\
(0.103)\end{array}$ & $\begin{array}{l}-0.047 \\
(0.077)\end{array}$ & $\begin{array}{c}-0.092 \\
(0.118)\end{array}$ & $\begin{array}{l}-0.029 \\
(0.109)\end{array}$ \\
\hline Observations & 300 & 300 & 300 & 300 & 300 & 300 & 300 \\
\hline R-squared & 0.029 & 0.035 & 0.014 & 0.017 & 0.042 & 0.018 & 0.012 \\
\hline
\end{tabular}

Notes: Robust standard errors in parentheses. ${ }^{* * *} \mathrm{p}<0.01,{ }^{* *} \mathrm{p}<0.05,{ }^{*} \mathrm{p}<0.1$. The dependent variable is change in Posyandu service at community level from 1997 to 2000. Covariates include duration of the PMT program (measured in 2000) and community characteristics (measured in 1997). 


\section{Table 6}

\section{Did the PMT Program Induce Fertility or Migration?}

Panel A. Fertility Response

\begin{tabular}{lcccc}
\hline & \multicolumn{3}{c}{ Number of Births Since Previous Round } & \multicolumn{2}{c}{$\begin{array}{c}\text { Change in Number of } \\
\text { Births 1997-2000 }\end{array}$} \\
\cline { 2 - 3 } & $(1)$ & $(2)$ & $(3)$ & $(4)$ \\
\hline $\begin{array}{l}\text { Program Duration (months) * } \\
\text { Year 2000 Dummy }\end{array}$ & -0.001 & -0.003 & 0.002 & 0.001 \\
Community Fixed Effect & $(0.001)$ & $(0.002)$ & $(0.002)$ & $(0.003)$ \\
$\begin{array}{l}\text { Observations } \\
\text { R-Squared }\end{array}$ & No & Yes & No & No \\
\hline
\end{tabular}

Notes: The sample is comprised of married women of child-bearing age who lived in enumeration areas with program information. Models (1) and (2) use a pooled sample of women from the 1997 and 2000 surveys, while the sample in models (3) and (4) uses women who were married and of child-bearing age in both survey rounds. Other regressors, shown in on-line Appendix Table A.3, include Education (years), Age (years), Age-Squared, a constant and, in models (1) and (2), a Year-2000 dummy. Standard errors, shown in parentheses, are robust to arbitrary within community (village) correlation. Except for community program duration, all covariates for models (3) and (4) are lags (from the 1997 survey round). $\left({ }^{* *}\right),\left(^{* *}\right),\left(^{*}\right)$ indicate significance levels of $1 \%, 5 \%$ and $10 \%$, respectively.

Panel B Migration

\begin{tabular}{|c|c|c|c|c|}
\hline & \multicolumn{3}{|c|}{ Migrated Out (yes=1) } & \multirow{2}{*}{$\begin{array}{l}\text { Change in Migration } \\
1997-2000 \\
(4)\end{array}$} \\
\hline & (1) & (2) & (3) & \\
\hline Program Duration (months) * & 0.001 & 0.001 & 0.000 & -0.002 \\
\hline Year 2000*Treatment Age & $(0.001)$ & $(0.001)$ & $(0.001)$ & $(0.002)$ \\
\hline Community Fixed Effect & No & Yes & No & No \\
\hline Observations & 7,342 & 7,342 & 1,573 & 1,573 \\
\hline R-Squared & 0.059 & 0.129 & 0.006 & 0.053 \\
\hline
\end{tabular}

Notes: The sample in model (1) and (2) includes both children in EAs with PMT information and those who moved out of the EA with their mothers since the previous survey round. In models (3) and (4), the sample is restricted to children appearing in both models (1) and (2). The sample is comprised of all children who are of age to be treated by the PMT (6-60 months) or in the control group (60-96 months) in IFLS 1997 and 2000 and includes those who lived in IFLS EAs in prior survey rounds (1993 and 1997) and moved out of IFLS EAs by the next round (1997 and 2000). Other regressors, shown in on-line Appendix Table A.4, include program duration, Education (years), Age (years), Age-Squared, Treatment Age (age greater than 6 and less than 60 months) marital status, a constant and, in models (1) and (2), a Year-2000 dummy. Standard errors, shown in parentheses, are robust to arbitrary within community correlation. Except for community program duration, all covariates for models (3) and (4) are lags (from the 1997 survey round). The number of observations $(7,342)$ is lower than our analysis sample because migration information is derived from mother information, and information on mother's location was missing for 264 children between the ages of 6 and 96 months. 
Table 7

Impact of PMT on Height-for-Age \& Stunting

\begin{tabular}{|c|c|c|c|c|}
\hline Age at Time of Survey in 2000 & $\begin{array}{c}\text { 6-11 } \\
\text { Months }\end{array}$ & $\begin{array}{l}12-23 \\
\text { months }\end{array}$ & $\begin{array}{l}24-60 \\
\text { months }\end{array}$ & $\begin{array}{l}\text { 60-96 } \\
\text { Months }\end{array}$ \\
\hline A. Height-for-Age & $\hat{\beta}^{1}$ & $\hat{\beta}^{2}$ & $\hat{\beta}^{3}$ & $\hat{\beta}^{c}$ \\
\hline $\begin{array}{l}\text { Duration of PMT in Comm. (months) } \\
\text { (standard error) }\end{array}$ & $\begin{array}{c}-0.011^{* * *} \\
(0.002)\end{array}$ & $\begin{array}{c}0.001 \\
(0.002)\end{array}$ & $\begin{array}{c}0.003 \\
(0.003)\end{array}$ & $\begin{array}{c}-0.008^{* * *} \\
(0.002)\end{array}$ \\
\hline & $\left(\hat{\beta}^{1}-\hat{\beta}^{c}\right)$ & $\left(\hat{\beta}^{2}-\hat{\beta}^{c}\right)$ & $\left(\hat{\beta}^{3}-\hat{\beta}^{c}\right)$ & \\
\hline $\begin{array}{l}\text { Diff-in-Diff Estimate } \\
\text { [p-value] }\end{array}$ & $\begin{array}{l}-0.003 \\
{[0.239]}\end{array}$ & $\begin{array}{c}0.009 \\
{[0.001]}\end{array}$ & $\begin{array}{c}0.011 \\
{[0.002]}\end{array}$ & $\begin{array}{l}- \\
-\end{array}$ \\
\hline & & $\left(\hat{\beta}^{2}-\hat{\beta}^{1}\right)$ & $\left(\hat{\beta}^{3}-\hat{\beta}^{2}\right)$ & \\
\hline $\begin{array}{l}\text { Diff-in-Diff Estimate } \\
\text { [p-value] }\end{array}$ & & $\begin{array}{c}0.012 \\
{[0.000]}\end{array}$ & $\begin{array}{c}0.002 \\
{[0.521]}\end{array}$ & $\begin{array}{c}- \\
-\end{array}$ \\
\hline B. Moderate Stunting (HAZ $<-2)$ & $\hat{\beta}^{1}$ & $\hat{\beta}^{2}$ & $\hat{\beta}^{3}$ & $\hat{\beta}^{c}$ \\
\hline $\begin{array}{l}\text { Duration of PMT in Comm. (months) x100 } \\
\text { (standard error) }\end{array}$ & $\begin{array}{l}0.095^{* *} \\
(0.047)\end{array}$ & $\begin{array}{c}-0.144^{* *} \\
(0.061)\end{array}$ & $\begin{array}{l}-0.092 \\
(0.109)\end{array}$ & $\begin{array}{c}0.148 \\
(0.106)\end{array}$ \\
\hline & $\left(\hat{\beta}^{1}-\hat{\beta}^{c}\right)$ & $\left(\hat{\beta}^{2}-\hat{\beta}^{c}\right)$ & $\left(\hat{\beta}^{3}-\hat{\beta}^{c}\right)$ & \\
\hline $\begin{array}{l}\text { Diff-in-Diff Estimate x100 } \\
\text { [p-value] }\end{array}$ & $\begin{array}{l}-0.052 \\
{[0.640]}\end{array}$ & $\begin{array}{c}-0.292 \\
{[0.011]}\end{array}$ & $\begin{array}{l}-0.240 \\
{[0.111]}\end{array}$ & - \\
\hline & & $\left(\hat{\beta}^{2}-\hat{\beta}^{1}\right)$ & $\left(\hat{\beta}^{3}-\hat{\beta}^{2}\right)$ & \\
\hline $\begin{array}{l}\text { Diff-in-Diff Estimate x100 } \\
\text { [p-value] }\end{array}$ & & $\begin{array}{c}-0.240 \\
{[0.001]}\end{array}$ & $\begin{array}{l}-0.052 \\
{[0.671]}\end{array}$ & - \\
\hline
\end{tabular}

\begin{tabular}{lcccc} 
C. Severe Stunting (HAZ<-3) & $\hat{\beta}^{1}$ & $\hat{\beta}^{2}$ & $\hat{\beta}^{3}$ & $\hat{\beta}^{c}$ \\
\hline $\begin{array}{l}\text { Duration of PMT in Comm (months) x100 } \\
\text { (standard error) }\end{array}$ & $0.077^{* * *}$ & -0.024 & $-0.147^{*}$ & $0.281^{* * *}$ \\
& $(0.029)$ & $(0.050)$ & $(0.085)$ & $(0.074)$ \\
& $\left(\hat{\beta}^{1}-\hat{\beta}^{c}\right)$ & $\left(\hat{\beta}^{2}-\hat{\beta}^{c}\right)$ & $\left(\hat{\beta}^{3}-\hat{\beta}^{c}\right)$ & \\
\cline { 2 - 5 } Diff-in-Diff Estimate x100 & $\mathbf{- 0 . 2 0 4}$ & $\mathbf{- 0 . 3 0 5}$ & $\mathbf{- 0 . 4 2 8}$ & - \\
[p-value] & {$[\mathbf{0 . 0 0 8}]$} & {$[\mathbf{0 . 0 0 0}]$} & {$[\mathbf{0 . 0 0 0 ]}$} & -
\end{tabular}

Diff-in-Diff Estimate x100

\begin{tabular}{ccc}
$\left(\hat{\beta}^{2}-\hat{\beta}^{1}\right)$ & $\left(\hat{\beta}^{3}-\hat{\beta}^{2}\right)$ & \\
-0.100 & -0.123 & - \\
{$[0.053]$} & {$[0.191]$} & - \\
\hline
\end{tabular}

[p-value]

Notes: Standard errors robust to arbitrary within community (village) correlation in parentheses. *** $\mathrm{p}<0.01,{ }^{* *} \mathrm{p}<0.05,{ }^{*} \mathrm{p}<0.1$. P-value for diff-in-diff parameter in bracket. Significant diff-in-diff estimates appear in bold. Regressions also include year dummy, program dummy, gender, age (a quadratic measured in months), per capita expenditure (ln), parental height, parental education, household demographic variables (male head, number of children, number of female and male adult), community characteristics (distance to bus station, whether main road is asphalt, availability of sewage and piped water. All specifications control for community fixed-effects. Source: IFLS 1997 and $2000(\mathrm{~N}=7606)$. 
Protecting Child Nutritional Status in the Aftermath of a Financial Crisis:

Evidence from Indonesia

John Giles and Elan Satriawan

Appendix Tables

To Be Made Available On-Line 
Figure A1

CDFs of Community Level Average Child Characteristics in 1997 and Program Duration in 2000

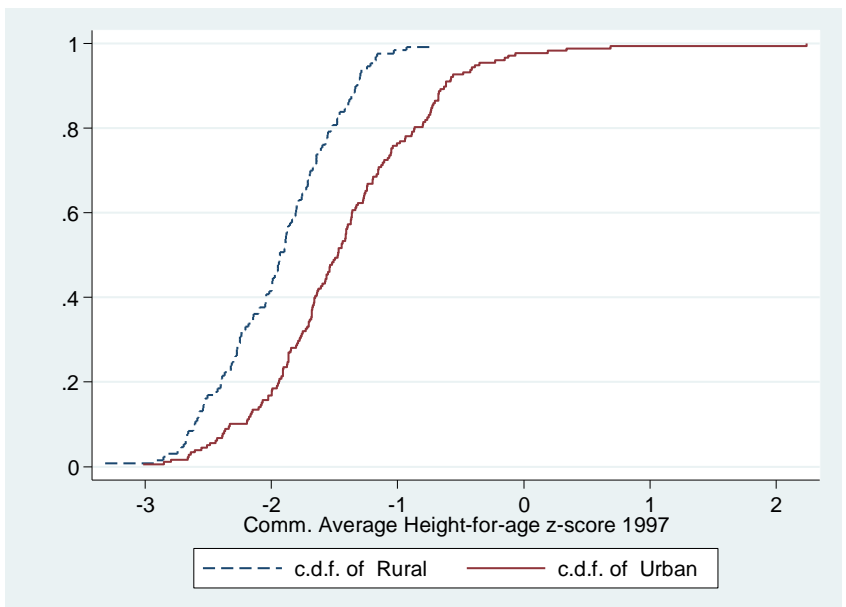

A. Community Average Height for Age

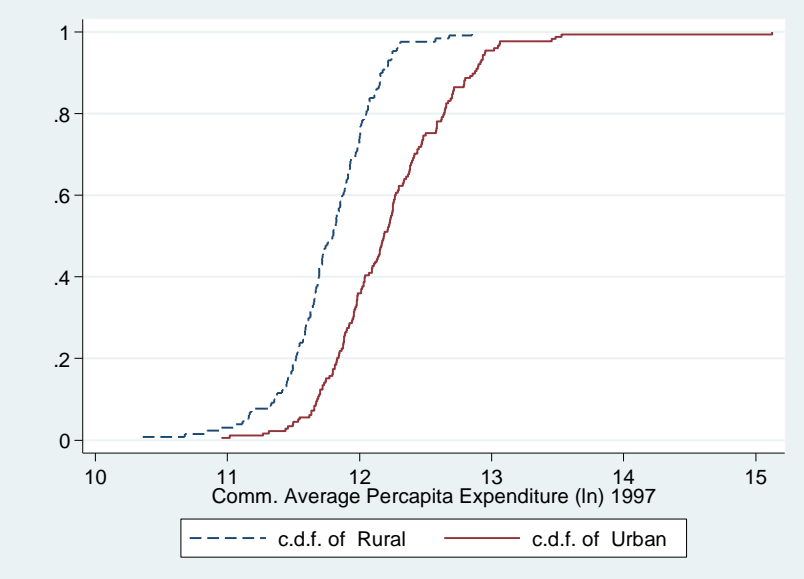

C. Community Average $\ln (\mathrm{PCE})$

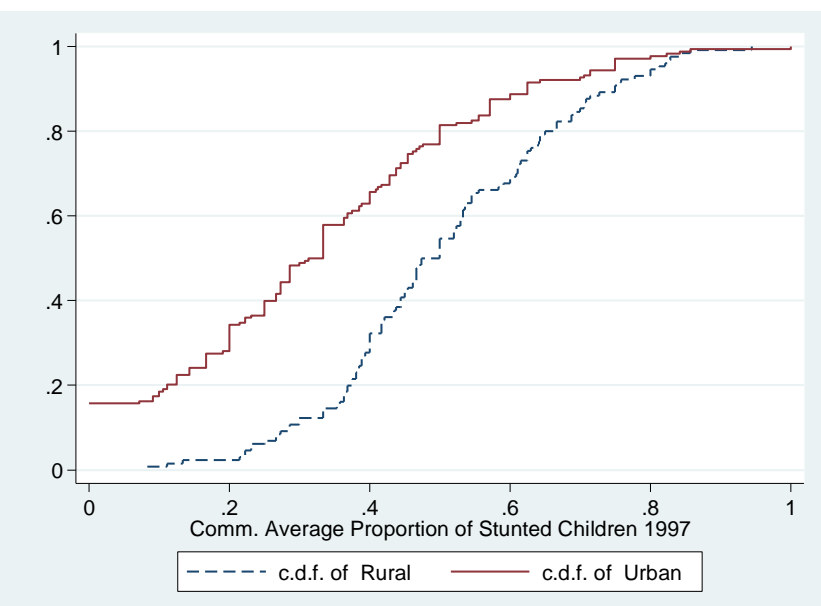

B. Community Average Proportion Stunted

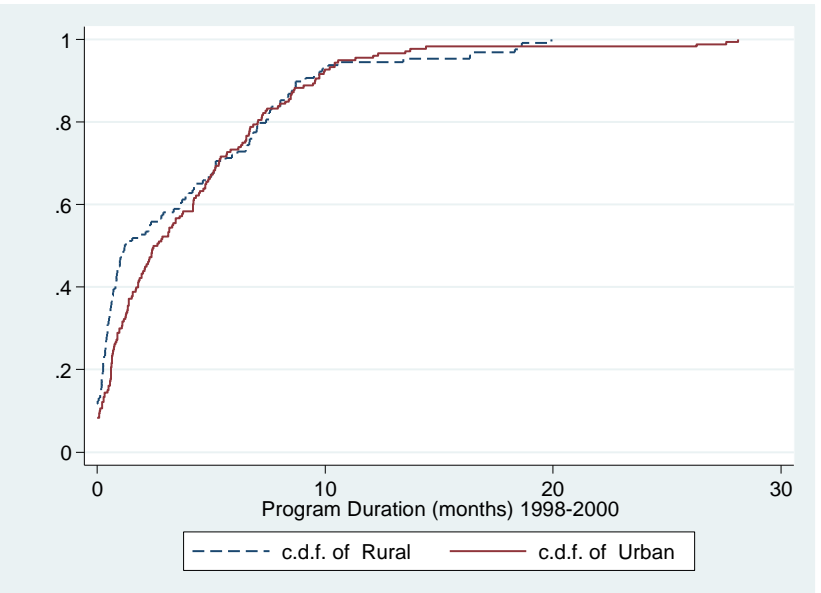

D. Program Duration

Sources: For A, B and C, IFLS (1997); for D, Community Infrastructure and Facility Survey, IFLS (2000). 
Figure A2

Age Distribution of Children Under 60 Months of Age

1997

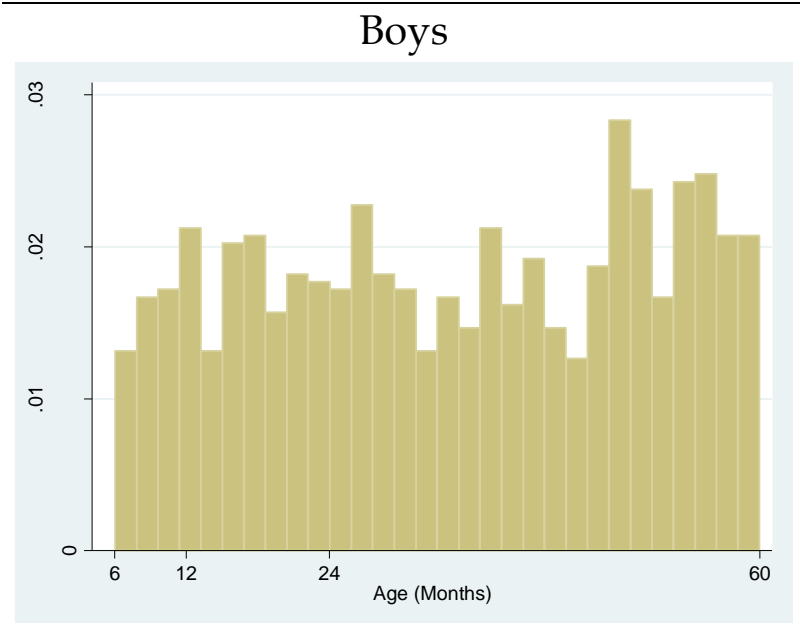

\section{Girls}

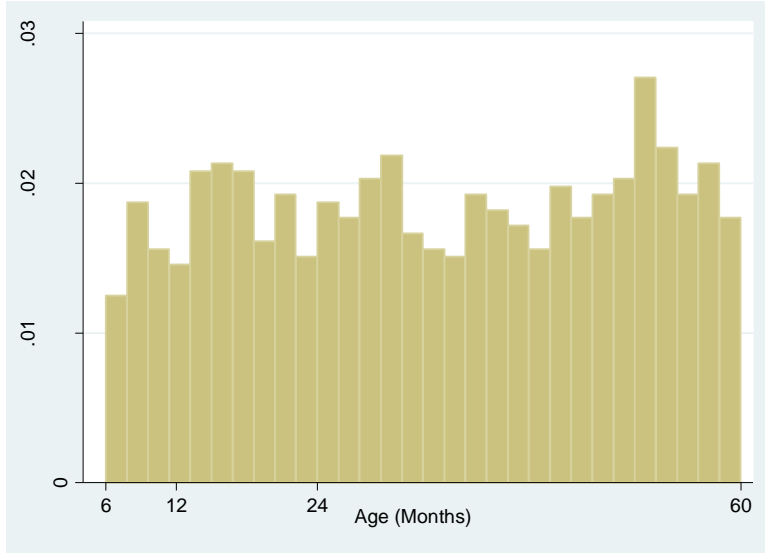

2000
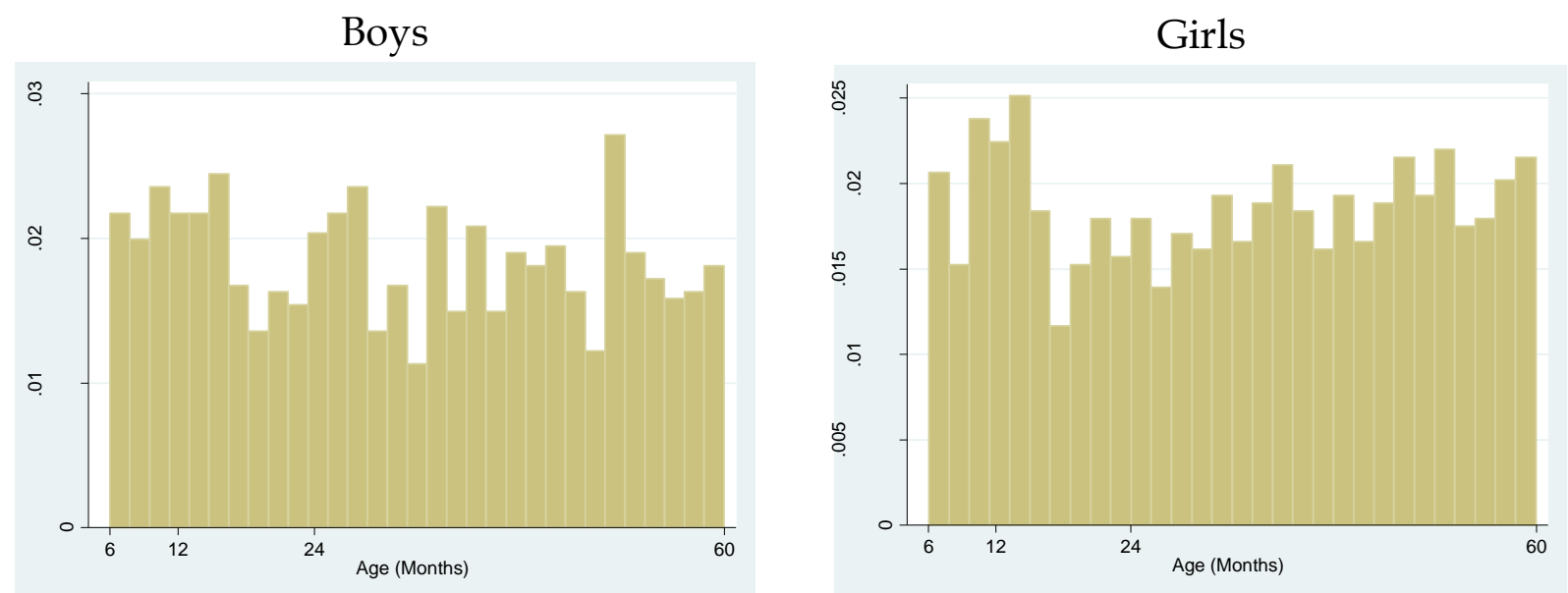

Source: Indonesia Family Life Survey $(1997,2000)$. 
Table A.1.

Number of Children Missing Height-for-Age Z-Scores under Standards Used by WHO 2006 and CDC 2000 Anthropometric Macros

(Unit: Number of Observations with Missing Values)

\begin{tabular}{lcc}
\hline & WHO 2006 Standard & CDC 2000 Standard \\
\hline 1997 & & \\
Age $<60$ months & 159 & 170 \\
Age $>=60$ months & 20 & 22 \\
Total & 179 & 192 \\
& & \\
2000 & 464 & 591 \\
Age $<60$ months & 250 & 261 \\
Age $>=60$ months & 714 & 852 \\
Total & & \\
\end{tabular}

Notes: Calculated from IFLS 1997 and 2000. 
Table A.2.

Is Missing Information on Height-for-Age Z-scores

Correlated with Program Duration?

(Dependent Variable: Missing HAZ Score = 1)

\begin{tabular}{lcc}
\hline & $(1)$ & $(2)$ \\
\hline & & \\
Year Dummy $(2000=1)$ & $0.105^{* * *}$ & $0.103^{* * *}$ \\
Treatment Age (Yes=1) & $(0.011)$ & $(0.011)$ \\
& $0.022^{*}$ & $0.023^{*}$ \\
Program Duration (months) & $(0.012)$ & $(0.013)$ \\
& 0.003 & -0.001 \\
Duration (months)*Year Dummy & $(0.003)$ & $(0.004)$ \\
$\quad$ Treatment Age & -0.003 & -0.000 \\
Age (months) & $(0.004)$ & $(0.005)$ \\
& 0.001 & 0.001 \\
Age-squared (months) & $(0.001)$ & $(0.001)$ \\
& $-0.000^{* *}$ & $-0.000^{*}$ \\
PCE (ln) & $(0.000)$ & $(0.000)$ \\
& $0.013^{* *}$ & $0.024^{* * *}$ \\
Constant & $(0.006)$ & $(0.006)$ \\
& -0.114 & $-0.238^{* * *}$ \\
Community Fixed-effect & $(0.076)$ & $(0.083)$ \\
& & \\
Observations & No & Yes \\
R-squared & & \\
Note: Dependent variable is missing height-for-age (Yes=1). The sample is comprised of \\
children between 6-96 months in 1997 or 2000 and residing in enumeration areas with PMT \\
information. Standard errors, shown in parentheses, are robust to arbitrary within community \\
(village) correlation. & & \\
\end{tabular}

Our main concerns are that program duration may be systematically related to exclusion from the analysis sample, due to non-response or due to exclusion by the 2006 anthropometric macro. To evaluate this possibility we regress an indicator for a missing height-for-age z-score on a year 2000 dummy, an indicator for being in treatment age (age 6 to 60 months), program duration in the community, program duration intereacted with year 2000 and treatment age, age, age-squared, $\ln (\mathrm{PCE})$ and a constant.

We note that there is no relationship between either program duration in the community and probability of a missing value. Further, from the interaction term, there is no evidence that treatment-age children receiving treatment were more or less likely to be excluded than control-age children.

As evident in Table 1, we note that missing height-for-age z-scores were more likely for the 2000 survey round than the 1997 round, and that younger children were more likely to be excluded. 
Table A.3. Did the PMT Program Induce Fertility?

(Full Results of Models Estimated in Table 6-Panel A)

\begin{tabular}{|c|c|c|c|c|}
\hline & \multicolumn{3}{|c|}{$\begin{array}{c}\text { Number of Births Since Previous } \\
\text { Round }\end{array}$} & \multirow{2}{*}{$\begin{array}{l}\text { Change in Number } \\
\text { of Births 1997-2000 } \\
(4)\end{array}$} \\
\hline & $(1)$ & $(2)$ & (3) & \\
\hline Year Dummy $(2000=1)$ & $\begin{array}{c}-0.092^{* * *} \\
(0.027)\end{array}$ & $\begin{array}{l}-0.077^{* *} \\
(0.034)\end{array}$ & $\begin{array}{l}- \\
-\end{array}$ & $\begin{array}{l}- \\
-\end{array}$ \\
\hline $\begin{array}{l}\text { Program Duration } \\
\text { (months)*Year Dummy }\end{array}$ & $\begin{array}{l}-0.001 \\
(0.001)\end{array}$ & $\begin{array}{l}-0.003 \\
(0.002)\end{array}$ & $\begin{array}{c}0.002 \\
(0.002)\end{array}$ & $\begin{array}{c}0.001 \\
(0.003)\end{array}$ \\
\hline Education (Years) & $\begin{array}{c}-0.005^{* * *} \\
(0.002)\end{array}$ & $\begin{array}{c}-0.005^{* * *} \\
(0.002)\end{array}$ & $\begin{array}{c}0.003 \\
(0.003)\end{array}$ & $\begin{array}{c}0.012^{* * *} \\
(0.004)\end{array}$ \\
\hline Age (Years) & $\begin{array}{l}-0.002 \\
(0.008)\end{array}$ & $\begin{array}{l}-0.007 \\
(0.008)\end{array}$ & $\begin{array}{c}0.029 \\
(0.023)\end{array}$ & $\begin{array}{c}0.043 \\
(0.049)\end{array}$ \\
\hline Age-squared & $\begin{array}{c}-0.000^{* * *} \\
(0.000)\end{array}$ & $\begin{array}{c}-0.000^{* *} \\
(0.000)\end{array}$ & $\begin{array}{l}-0.001^{* *} \\
(0.000)\end{array}$ & $\begin{array}{l}-0.001 \\
(0.001)\end{array}$ \\
\hline Constant & $\begin{array}{c}1.369 * * * \\
(0.116)\end{array}$ & $\begin{array}{c}1.439 * * * \\
(0.122)\end{array}$ & $\begin{array}{l}0.786^{* *} \\
(0.345)\end{array}$ & $\begin{array}{l}-0.591 \\
(0.704)\end{array}$ \\
\hline $\begin{array}{l}\text { Community Fixed-effect } \\
\text { Error Clustered at Comm Level }\end{array}$ & $\begin{array}{l}\text { No } \\
\text { Yes }\end{array}$ & $\begin{array}{l}\text { Yes } \\
\text { Yes }\end{array}$ & $\begin{array}{l}\text { No } \\
\text { Yes }\end{array}$ & $\begin{array}{l}\text { No } \\
\text { Yes }\end{array}$ \\
\hline $\begin{array}{l}\text { Observations } \\
\text { R-squared }\end{array}$ & $\begin{array}{l}5,444 \\
0.106\end{array}$ & $\begin{array}{l}5,444 \\
0.170\end{array}$ & $\begin{array}{c}803 \\
0.102\end{array}$ & $\begin{array}{c}803 \\
0.034\end{array}$ \\
\hline
\end{tabular}

Notes: The sample is comprised of married women of child-bearing age who lived in enumeration areas with program information. Models (1) and (2) use a pooled sample of women from 1997 and 2000 surveys, while the sample in models (3) and (4) uses women who were married and of child-bearing age in both survey rounds. Standard errors, shown in parentheses, are robust to arbitrary within community (village) correlation. Except for community program duration, all covariates for models (3) and (4) are lags (from the 1997 survey round). $\left.{ }^{(* *}\right),\left({ }^{* *}\right),\left(^{*}\right)$ indicate significance levels of $1 \%, 5 \%$ and $10 \%$, respectively. 


\section{Table A.4. Did the PMT Program Affect Rates of Out-Migration? (Full Results of Models Estimated in Table 6-Panel B)}

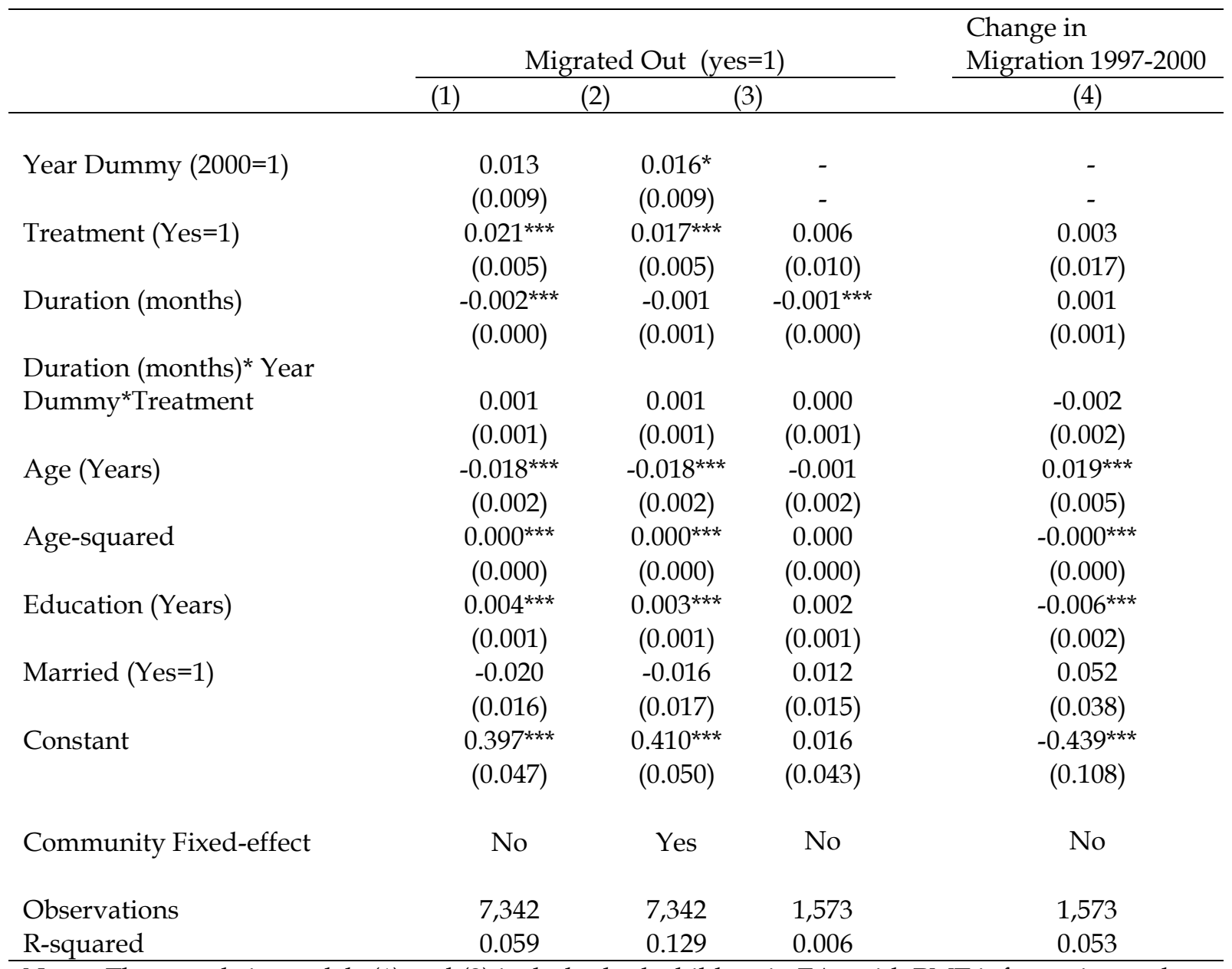

Notes: The sample in models (1) and (2) includes both children in EAs with PMT information and those who moved out of the EA with their mothers since the previous survey round. In models (3) and (4), the sample is restricted to children appearing in both models (1) and (2). The sample is comprised of all children who are of age to be treated by the PMT (6-60 months) or in the control group (60-96 months) in IFLS 1997 and 2000 and includes those who lived in IFLS EAs in prior survey rounds (1993 and 1997) and moved out of IFLS EAs by the next round (1997 and 2000). Other regressors include program duration, Education (years), Age (years), Age-Squared, Treatment Age (age greater than 6 and less than 60 months) marital status, a constant and, in models (1) and (2), a Year-2000 dummy. Standard errors, shown in parentheses, are robust to arbitrary within community (village) correlation. Except for community program duration, all covariates for models (3) and (4) are lags (from the 1997 survey round). The number of observations $(7,342)$ is lower than our analysis sample because migration information is derived from mother information, and information on mother's location was missing for 264 children between the ages of 6 and 96 months. 
Table A.5

Estimated Impact at Different Levels of Program Duration

Panel A: Impact Calculated from $\left(\hat{\beta}^{1}-\hat{\beta}^{c}\right)$

\begin{tabular}{lcccc}
\hline Percentile in & Program & \multicolumn{3}{c}{ Estimated Impact } \\
\cline { 3 - 5 } $\begin{array}{l}\text { Distribution } \\
\text { of Duration }\end{array}$ & $\begin{array}{c}\text { Duration } \\
\text { (Months) }\end{array}$ & $\begin{array}{c}\text { Height-for-Age } \\
(\text { SD) }\end{array}$ & $\begin{array}{c}\text { \% Moderate } \\
\text { Stunting x100 }\end{array}$ & $\begin{array}{c}\text { \% Severe } \\
\text { Stunting } \times 100\end{array}$ \\
\hline $10^{\text {th }}$ & 0.67 & - & - & -0.137 \\
$25^{\text {th }}$ & 1.46 & - & - & -0.298 \\
$50^{\text {th }}$ & 6.47 & - & - & -1.320 \\
$75^{\text {th }}$ & 13.65 & - & - & -2.785 \\
$90^{\text {th }}$ & 14.80 & - & - & -3.019 \\
\hline
\end{tabular}

Panel B: Impact Calculated from $\left(\hat{\beta}^{2}-\hat{\beta}^{c}\right)$

\begin{tabular}{lcccc}
\hline Percentile in & Program & \multicolumn{3}{c}{ Estimated Impact } \\
\cline { 3 - 5 } $\begin{array}{l}\text { Distribution } \\
\text { of Duration }\end{array}$ & $\begin{array}{c}\text { Duration } \\
\text { (Months) }\end{array}$ & $\begin{array}{c}\text { Height-for-Age } \\
\text { \% Moderate }\end{array}$ & $\begin{array}{c}\text { \% Severe } \\
\text { Stunting } \times 100\end{array}$ & Stunting x100 \\
\hline $10^{\text {th }}$ & 0.67 & 0.006 & -0.196 & -0.204 \\
$25^{\text {th }}$ & 1.46 & 0.013 & -0.426 & -0.445 \\
$50^{\text {th }}$ & 6.47 & 0.058 & -1.889 & -1.973 \\
$75^{\text {th }}$ & 13.65 & 0.123 & -3.986 & -4.163 \\
$90^{\text {th }}$ & 14.80 & 0.133 & -4.322 & -4.514 \\
\hline
\end{tabular}

Panel C: Impact Calculated from $\left(\hat{\beta}^{3}-\hat{\beta}^{c}\right)$

\begin{tabular}{lcccc}
\hline Percentile in & Program & \multicolumn{3}{c}{ Estimated Impact } \\
\cline { 3 - 5 } $\begin{array}{l}\text { Distribution } \\
\text { of Duration }\end{array}$ & $\begin{array}{c}\text { Duration } \\
\text { (Months) }\end{array}$ & $\begin{array}{c}\text { Height-for-Age } \\
(\text { SD) }\end{array}$ & $\begin{array}{c}\text { \% Moderate } \\
\text { Stunting x100 }\end{array}$ & $\begin{array}{c}\text { \% Severe } \\
\text { Stunting x100 }\end{array}$ \\
\hline $10^{\text {th }}$ & 0.67 & 0.007 & - & -0.287 \\
$25^{\text {th }}$ & 1.46 & 0.016 & - & -0.625 \\
$50^{\text {th }}$ & 6.47 & 0.071 & - & -2.769 \\
$75^{\text {th }}$ & 13.65 & 0.150 & - & -5.842 \\
$90^{\text {th }}$ & 14.80 & 0.163 & - & -6.334 \\
\hline
\end{tabular}

Notes: The impacts are based on difference-in-difference estimates shown in Table 7 above. Panel A, B and C respectively show impact on standardized height-for-age and Severe stunting for 6 to 12,12 to 24 , and 24 to 60 months old children calculated by differencing coefficients on each of treatment group with the control group. The estimated impacts are based on models that control for presence of a pre-natal program when children were in utero. 
Table A.6

Impact of PMT on Height-for-Age \& Stunting

(Sample Includes Children who No Longer Lived in the EA in 2000)

\begin{tabular}{lcccc}
\hline Age at Time of Survey in $\mathbf{2 0 0 0}$ & $\begin{array}{c}6-11 \\
\text { Months }\end{array}$ & $\begin{array}{c}12-23 \\
\text { months }\end{array}$ & $\begin{array}{c}24-60 \\
\text { months }\end{array}$ & $\begin{array}{c}60-96 \\
\text { Months }\end{array}$ \\
\hline A. Height-for-Age & $\hat{\beta}^{1}$ & $\hat{\beta}^{2}$ & $\hat{\beta}^{3}$ & $\hat{\beta}^{c}$ \\
\hline Duration of PMT in Comm. (months) & $-0.007^{* * *}$ & -0.002 & 0.002 & $-0.005^{* * *}$ \\
(standard error) & $(0.002)$ & $(0.002)$ & $(0.002)$ & $(0.002)$ \\
& & & \\
& $\left(\hat{\beta}^{1}-\hat{\beta}^{c}\right)$ & $\left(\hat{\beta}^{2}-\hat{\beta}^{c}\right)$ & $\left(\widehat{\boldsymbol{\beta}}^{\mathbf{3}}-\widehat{\boldsymbol{\beta}}^{c}\right)$ & \\
Diff-in-Diff Estimate & -0.002 & 0.003 & $\mathbf{0 . 0 0 7}$ & - \\
[p-value] & {$[0.529]$} & {$[0.238]$} & {$[\mathbf{0 . 0 3 0 ]}$} & - \\
& & & & \\
& & $\left(\widehat{\boldsymbol{\beta}}^{2}-\widehat{\boldsymbol{\beta}}^{\mathbf{1}}\right)$ & $\left(\hat{\beta}^{3}-\hat{\beta}^{2}\right)$ & \\
Diff-in-Diff Estimate & & $\mathbf{0 . 0 0 5}$ & 0.004 & - \\
[p-value] & & $\mathbf{0 . 0 1 9 ]}$ & {$[0.149]$} & - \\
\hline
\end{tabular}

\begin{tabular}{|c|c|c|c|c|}
\hline B. Moderate Stunting (HAZ<-2) & $\hat{\beta}^{1}$ & $\hat{\beta}^{2}$ & $\hat{\beta}^{3}$ & $\hat{\beta}^{c}$ \\
\hline $\begin{array}{l}\text { Duration of PMT in Comm. (months) x100 } \\
\text { (standard error) }\end{array}$ & $\begin{array}{l}0.095^{* *} \\
(0.045)\end{array}$ & $\begin{array}{l}-0.029 \\
(0.053)\end{array}$ & $\begin{array}{l}-0.164 \\
(0.095)\end{array}$ & $\begin{array}{l}0.0065 \\
(0.550)\end{array}$ \\
\hline \multirow{3}{*}{$\begin{array}{l}\text { Diff-in-Diff Estimate } x 100 \\
\text { [p-value] }\end{array}$} & $\left(\hat{\beta}^{1}-\hat{\beta}^{c}\right)$ & $\left(\hat{\beta}^{2}-\hat{\beta}^{c}\right)$ & $\left(\hat{\beta}^{3}-\hat{\beta}^{c}\right)$ & \\
\hline & $\begin{array}{c}0.030 \\
{[0.790]}\end{array}$ & $\begin{array}{l}-0.094 \\
{[0.422]}\end{array}$ & $\begin{array}{c}-0.228 \\
{[0.114]}\end{array}$ & - \\
\hline & & $\left(\widehat{\beta}^{2}-\widehat{\beta}^{1}\right)$ & $\left(\hat{\beta}^{3}-\hat{\beta}^{2}\right)$ & \\
\hline $\begin{array}{l}\text { Diff-in-Diff Estimate x100 } \\
\text { [p-value] }\end{array}$ & & $\begin{array}{l}-0.123 \\
{[0.046]}\end{array}$ & $\begin{array}{l}-0.135 \\
{[0.211]}\end{array}$ & - \\
\hline C. Severe Stunting $(\mathrm{HAZ}<-3)$ & $\hat{\beta}^{1}$ & $\hat{\beta}^{2}$ & $\hat{\beta}^{3}$ & $\hat{\beta}^{c}$ \\
\hline $\begin{array}{l}\text { Duration of PMT in Comm (months) x100 } \\
\text { (standard error) }\end{array}$ & $\begin{array}{l}0.044^{*} \\
(0.025)\end{array}$ & $\begin{array}{c}0.011 \\
(0.043)\end{array}$ & $\begin{array}{l}-0.144^{*} \\
(0.075)\end{array}$ & $\begin{array}{r}0.225^{* * *} \\
(0.073)\end{array}$ \\
\hline \multirow{3}{*}{$\begin{array}{l}\text { Diff-in-Diff Estimate x100 } \\
\text { [p-value] }\end{array}$} & $\left(\hat{\beta}^{1}-\hat{\beta}^{c}\right)$ & $\left(\hat{\beta}^{2}-\hat{\beta}^{c}\right)$ & $\left(\hat{\beta}^{3}-\hat{\beta}^{c}\right)$ & \\
\hline & $\begin{array}{l}-0.181 \\
{[0.015]}\end{array}$ & $\begin{array}{l}-0.214 \\
{[0.009]}\end{array}$ & $\begin{array}{l}-0.369 \\
{[0.000]}\end{array}$ & - \\
\hline & & $\left(\hat{\beta}^{2}-\hat{\beta}^{1}\right)$ & $\left(\hat{\beta}^{3}-\hat{\beta}^{2}\right)$ & \\
\hline $\begin{array}{l}\text { Diff-in-Diff Estimate } x 100 \\
\text { [p-value] }\end{array}$ & & $\begin{array}{l}-0.003 \\
{[0.474]}\end{array}$ & $\begin{array}{l}-0.156 \\
{[0.063]}\end{array}$ & - \\
\hline
\end{tabular}

Notes: Standard errors robust to arbitrary within community (village) correlation in parentheses. *** $\mathrm{p}<0.01,{ }^{* *} \mathrm{p}<0.05,{ }^{*} \mathrm{p}<0.1$. P-value for diff-in-diff parameter in bracket. Significant diff-in-diff estimates appear in bold. Regressions also include year dummy, program dummy, gender, age (a quadratic measured in months), per capita expenditure (ln), parental height, parental education, household demographic variables (male head, number of children, number of female and male adult), community characteristics (distance to bus station, whether main road is asphalt, availability of sewage and piped water. All specifications control for community fixed-effects. Source: IFLS 1997 and $2000(\mathrm{~N}=8273)$. 
Table A.7. Impact of PMT on Height-for-Age (HAZ) and Stunting (HAZ<-2 and HAZ<-3): Boy and Girls

\begin{tabular}{|c|c|c|c|c|c|c|}
\hline \multirow[b]{2}{*}{$\begin{array}{l}\text { Panel A. Program Parameter } \\
\text { Duration of PMT in the } \\
\text { Community(months) }\end{array}$} & \multicolumn{2}{|c|}{$\begin{array}{l}\text { Height-for-Age } \\
\text { (SD) }\end{array}$} & \multicolumn{2}{|c|}{$\begin{array}{c}\text { Moderate } \\
\text { Stunting x100 }\end{array}$} & \multicolumn{2}{|c|}{$\begin{array}{c}\text { Severe } \\
\text { Stunting } \times 100\end{array}$} \\
\hline & Boy & Girl & Boy & Girl & Boy & Girl \\
\hline Treatment: & & & & & & \\
\hline 6-11 months $\left(\hat{\beta}^{1}\right)$ & $\begin{array}{l}-0.013^{* * *} \\
(0.003)\end{array}$ & $\begin{array}{l}-0.007^{* *} \\
(0.003)\end{array}$ & $\begin{array}{l}0.153^{*} \\
(0.085)\end{array}$ & $\begin{array}{l}0.028 \\
(0.088)\end{array}$ & $\begin{array}{l}0.101^{*} \\
(0.060)\end{array}$ & $\begin{array}{l}0.047 \\
(0.065)\end{array}$ \\
\hline $12-23$ months $\left(\hat{\beta}^{2}\right)$ & $\begin{array}{l}0.004 \\
(0.003)\end{array}$ & $\begin{array}{l}-0.002 \\
(0.003)\end{array}$ & $\begin{array}{l}-0.232^{* *} \\
(0.094)\end{array}$ & $\begin{array}{l}-0.072 \\
(0.096)\end{array}$ & $\begin{array}{l}-0.111 \\
(0.084)\end{array}$ & $\begin{array}{l}0.045 \\
(0.080)\end{array}$ \\
\hline $24-59$ months $\left(\hat{\beta}^{3}\right)$ & $\begin{array}{l}0.005 \\
(0.004)\end{array}$ & $\begin{array}{l}0.001 \\
(0.004)\end{array}$ & $\begin{array}{l}0.023 \\
(0.143)\end{array}$ & $\begin{array}{l}-0.215 \\
(0.152)\end{array}$ & $\begin{array}{l}-0.258^{* *} \\
(0.113)\end{array}$ & $\begin{array}{l}-0.021 \\
(0.116)\end{array}$ \\
\hline $\begin{array}{l}\text { Control: } \\
60-95 \text { months }\left(\hat{\beta}^{c}\right)\end{array}$ & $\begin{array}{l}-0.010^{* * *} \\
(0.003)\end{array}$ & $\begin{array}{l}-0.006 \\
(0.003)\end{array}$ & $\begin{array}{l}0.301^{*} \\
(0.154)\end{array}$ & $\begin{array}{l}-0.023 \\
(0.155)\end{array}$ & $\begin{array}{l}0.234^{* *} \\
(0.108)\end{array}$ & $\begin{array}{l}0.318^{* * *} \\
(0.098)\end{array}$ \\
\hline
\end{tabular}

\begin{tabular}{|c|c|c|c|c|c|c|c|c|c|}
\hline \multirow{2}{*}{$\begin{array}{l}\text { Panel B. Diff-in-Diff } \\
\text { Parameter } \\
\left(\hat{\beta}^{1}-\hat{\beta}^{c}\right)\end{array}$} & \multicolumn{2}{|c|}{$\begin{array}{l}\text { Height-for-Age } \\
\text { (SD) }\end{array}$} & \multirow[t]{2}{*}{ sig } & \multicolumn{2}{|c|}{$\begin{array}{c}\text { Moderate } \\
\text { Stunting x100 }\end{array}$} & \multirow[t]{2}{*}{ sig } & \multicolumn{2}{|c|}{$\begin{array}{c}\text { Severe } \\
\text { Stunting } \times 100\end{array}$} & sig \\
\hline & -0.004 & -0.002 & & -0.149 & 0.051 & & -0.134 & -0.271 & \\
\hline & [0.341] & [0.677] & & [0.385] & {$[0.760]$} & & [0.268] & [0.016] & \\
\hline$\left(\hat{\beta}^{2}-\hat{\beta}^{c}\right)$ & 0.014 & 0.004 & + & -0.533 & -0.049 & ++ & -0.346 & -0.273 & \\
\hline & [0.002] & [0.348] & & [0.003] & [0.780] & & [0.011] & [0.026] & \\
\hline$\left(\hat{\beta}^{3}-\hat{\beta}^{c}\right)$ & 0.015 & 0.007 & & -0.278 & -0.192 & & -0.492 & -0.339 & \\
\hline & [0.004] & [0.178] & & [0.188] & [0.368] & & [0.002] & [0.025] & \\
\hline$\left(\hat{\beta}^{2}-\hat{\beta}^{1}\right)$ & 0.018 & 0.006 & ++ & -0.385 & -0.100 & ++ & -0.212 & -0.002 & ++ \\
\hline & [0.000] & [0.096] & & [0.000] & [0.345] & & [0.013] & [0.980] & \\
\hline$\left(\hat{\beta}^{3}-\hat{\beta}^{2}\right)$ & 0.001 & 0.005 & & 0.255 & -0.143 & & -0.146 & -0.065 & \\
\hline & [0.861] & [0.586] & & [0.122] & [0.405] & & [0.272] & [0.621] & \\
\hline \# of Obs & 3899 & 3707 & & 3899 & 3707 & & 3899 & 3707 & \\
\hline
\end{tabular}

Notes: Standard errors robust to arbitrary within community (village) correlation in parentheses. ${ }^{* * *} \mathrm{p}<0.01{ }^{* * *}$ $\mathrm{p}<0.05,{ }^{*} \mathrm{p}<0.1$. P-value for diff-in-diff parameter in bracket. $\left({ }^{+++}\right),\left({ }^{++}\right)$, and $\left({ }^{+}\right)$respectively indicate $1 \%, 5 \%$ and $10 \%$ significant difference between diff-in-diff parameter of boy and girl. Regressions also include year dummy, program dummy, control for prenatal program, gender, age (a quadratic measured in months), per capita expenditure (ln), parental height, parental education, household demographic variables (male head, number of children, number of female and male adult), community characteristics (distance to bus station, whether main road is asphalt, availability of sewage and piped water. All specifications control for community fixed-effects. Source: IFLS 1997 and 2000. 


\section{Table A.8. Estimated Impact on Boys' Nutritional Status at Different Levels of Program Duration}

Panel A: Impact Calculated from $\left(\hat{\beta}^{1}-\hat{\beta}^{c}\right)$

\begin{tabular}{lcccc}
\hline Percentile in & Program & \multicolumn{3}{c}{ Estimated Impact } \\
\cline { 3 - 5 } $\begin{array}{l}\text { Distribution } \\
\text { of Duration }\end{array}$ & $\begin{array}{c}\text { Duration } \\
\text { (Months) }\end{array}$ & $\begin{array}{c}\text { Height-for-Age } \\
\text { (SD) }\end{array}$ & $\begin{array}{c}\text { \% Moderate } \\
\text { Stunting x100 }\end{array}$ & $\begin{array}{c}\text { \% Severe } \\
\text { Stunting } \times 100\end{array}$ \\
\hline $10^{\text {th }}$ & 0.67 & - & - & - \\
$25^{\text {th }}$ & 1.46 & - & - & - \\
$50^{\text {th }}$ & 6.47 & - & - & - \\
$75^{\text {th }}$ & 13.65 & - & - & - \\
$90^{\text {th }}$ & 14.80 & - & - & - \\
\hline
\end{tabular}

Panel B: Impact Calculated from $\left(\hat{\beta}^{2}-\hat{\beta}^{c}\right)$

\begin{tabular}{|c|c|c|c|c|}
\hline \multirow{2}{*}{$\begin{array}{l}\text { Percentile in } \\
\text { Distribution } \\
\text { of Duration }\end{array}$} & \multirow{2}{*}{$\begin{array}{l}\text { Program } \\
\text { Duration } \\
\text { (Months) }\end{array}$} & \multicolumn{2}{|c|}{ Estimated Impact } & \multirow[b]{2}{*}{$\begin{array}{c}\% \text { Severe } \\
\text { Stunting x100 }\end{array}$} \\
\hline & & $\begin{array}{l}\text { Height-for-Age } \\
\text { (SD) }\end{array}$ & $\begin{array}{c}\text { \% Moderate } \\
\text { Stunting x100 }\end{array}$ & \\
\hline $10^{\text {th }}$ & 0.67 & 0.009 & -0.357 & -0.232 \\
\hline $25^{\text {th }}$ & 1.46 & 0.020 & -0.778 & -0.505 \\
\hline $50^{\text {th }}$ & 6.47 & 0.091 & -3.449 & -2.239 \\
\hline $7^{\text {th }}$ & 13.65 & 0.191 & -7.275 & -4.723 \\
\hline $90^{\text {th }}$ & 14.80 & 0.207 & -7.888 & -5.121 \\
\hline
\end{tabular}

Panel C: Impact Calculated from $\left(\hat{\beta}^{3}-\hat{\beta}^{c}\right)$

\begin{tabular}{lcccc}
\hline Percentile in & Program & \multicolumn{3}{c}{ Estimated Impact } \\
\cline { 3 - 5 } $\begin{array}{l}\text { Distribution } \\
\text { of Duration }\end{array}$ & $\begin{array}{c}\text { Duration } \\
\text { (Months) }\end{array}$ & $\begin{array}{c}\text { Height-for-Age } \\
(S D)\end{array}$ & $\begin{array}{c}\text { \% Moderate } \\
\text { Stunting x100 }\end{array}$ & $\begin{array}{c}\text { \% Severe } \\
\text { Stunting x100 }\end{array}$ \\
\hline $10^{\text {th }}$ & 0.67 & 0.010 & - & -0.330 \\
$25^{\text {th }}$ & 1.46 & 0.022 & - & -0.718 \\
$50^{\text {th }}$ & 6.47 & 0.097 & - & -3.183 \\
$75^{\text {th }}$ & 13.65 & 0.205 & - & -6.716 \\
$90^{\text {th }}$ & 14.80 & 0.222 & - & -7.282 \\
\hline
\end{tabular}

Notes: The impacts are based on difference-in-difference estimates shown in Tables 9 and 10 above. Panel A shows impact on 12 to 23 month old children calculated by coefficients on this treatment group with the control group, and Panel B shows impact of the 12-24 month treatment, calculated by differencing the effects of treatment on the 12 to 24 month group with the 6 to 12 month group. The estimated impacts are based on models that control for presence of a pre-natal program when children were in utero. 


\section{Table A.9. Control Experiment to Assess whether Results Reflect a Trend}

Are Results Driven By A Trend? The framework used in the paper should be robust to unobserved differences in health status trends and motivations of village leaders, that might drive support for the PMT program. To examine this possibility further, we also implemented a "control experiment" in which we examine the differences across two groups of children who were too old to be exposed to the program (those aged 60 to 95 and 96 to 120 months, respectively). We examine the correlation of months of exposure to the PMT nutrition program with their height for age of z-scores of two groups of children. If we observe a "program effect" on the younger control group, then this would suggest that our earlier analysis was picking up unobservable differences in trends as opposed to actual impacts of the program. Results of the control experiment are shown below for 2006 WHO curves and Table A.8 for 2000 CDC curves. We do not find any systematic difference across these subgroups in the relationship between exposure to the PMT and height for age z-scores.

Panel A. Impact of PMT on Height for Age

\begin{tabular}{lccc}
\hline Age at Time of Survey & Control 1 & Control 2 & Difference \\
& $60-95$ & $96-120$ & \\
Months & Months & \\
\hline \multirow{3}{*}{ Months of Community Exposure to PMT } & $-0.011^{* *}$ & -0.005 & -0.006 \\
& $(0.004)$ & $(0.004)$ & {$[0.278]$}
\end{tabular}

Panel B. Impact of PMT on Moderate Stunting

Months of Community Exposure to PMT

0.141

0.200

$-0.059$

x100

(0.192)

$(0.178)$

[0.818]

Panel C. Impact of PMT on Severe Stunting

Months of Community Exposure to PMT $\quad 0.346^{* *} \quad 0.212^{*} \quad 0.134$

x100

(0.164)

$(0.128)$

[0.508]

Notes: Standard errors robust to arbitrary within community (village) correlation in parentheses. *** $\mathrm{p}<0.01,{ }^{* *} \mathrm{p}<0.05,{ }^{*} \mathrm{p}<0.1$. P-value for diff-in-diff parameter in bracket. Significant diff-in-diff estimates appear in bold. Regressions also include year dummy, program dummy, presence of prenatal program, gender, age (a quadratic measured in months), per capita expenditure (ln), parental height, parental education, household demographic variables (male head, number of children, number of female and male adult), community characteristics (distance to bus station, whether main road is asphalt, availability of sewage and piped water. All specifications control for community fixed-effects. Source: IFLS 1997 and $2000(\mathrm{~N}=5645)$. 
Table A.10. Impact of PMT on Height-for-Age \& Stunting

(Ref Group: CDC 2000)

\begin{tabular}{|c|c|c|c|c|}
\hline Age at Time of Survey in 2000 & $\begin{array}{c}6-11 \\
\text { Months }\end{array}$ & $\begin{array}{c}12-23 \\
\text { months }\end{array}$ & $\begin{array}{l}24-60 \\
\text { months }\end{array}$ & $\begin{array}{l}\text { 60-96 } \\
\text { Months }\end{array}$ \\
\hline A. Height-for-Age & $\hat{\beta}^{1}$ & $\hat{\beta}^{2}$ & $\hat{\beta}^{3}$ & $\hat{\beta}^{c}$ \\
\hline $\begin{array}{l}\text { Duration of PMT in Community (months) } \\
\text { (standard error) }\end{array}$ & $\begin{array}{c}-0.007^{* * *} \\
(0.002)\end{array}$ & $\begin{array}{l}0.0002 \\
(0.002)\end{array}$ & $\begin{array}{c}0.003 \\
(0.003)\end{array}$ & $\begin{array}{c}-0.000^{* *} \\
(0.002)\end{array}$ \\
\hline & $\left(\hat{\beta}^{1}-\hat{\beta}^{c}\right)$ & $\left(\hat{\beta}^{2}-\hat{\beta}^{c}\right)$ & $\left(\hat{\beta}^{3}-\hat{\beta}^{c}\right)$ & \\
\hline $\begin{array}{l}\text { Diff-in-Diff Estimate } \\
\text { [p-value] }\end{array}$ & $\begin{array}{l}-0.001 \\
{[0.617]}\end{array}$ & $\begin{array}{c}0.006 \\
{[0.029]}\end{array}$ & $\begin{array}{c}0.008 \\
{[0.015]}\end{array}$ & - \\
\hline & & $\left(\hat{\beta}^{2}-\hat{\beta}^{1}\right)$ & $\left(\hat{\beta}^{3}-\hat{\beta}^{2}\right)$ & \\
\hline $\begin{array}{l}\text { Diff-in-Diff Estimate } \\
\text { [p-value] }\end{array}$ & & $\begin{array}{c}0.008 \\
{[0.001]} \\
\end{array}$ & $\begin{array}{c}0.003 \\
{[0.368]} \\
\end{array}$ & $\begin{array}{l}- \\
-\end{array}$ \\
\hline B. Moderate Stunting $(\mathrm{HAZ}<-2)$ & $\hat{\beta}^{1}$ & $\hat{\beta}^{2}$ & $\hat{\beta}^{3}$ & $\hat{\beta}^{c}$ \\
\hline $\begin{array}{l}\text { Duration of PMT in Community (months) x100 } \\
\text { (standard error) }\end{array}$ & $\begin{array}{c}0.054 \\
(0.043)\end{array}$ & $\begin{array}{l}-0.083 \\
(0.064)\end{array}$ & $\begin{array}{l}-0.164 \\
(0.106)\end{array}$ & $\begin{array}{c}0.144 \\
(0.116)\end{array}$ \\
\hline $\begin{array}{l}\text { Diff-in-Diff Estimate x100 } \\
\text { [p-value] }\end{array}$ & $\begin{array}{c}\left(\hat{\beta}^{1}-\hat{\beta}^{c}\right) \\
-0.089 \\
{[0.470]}\end{array}$ & $\begin{array}{c}\left(\hat{\beta}^{2}-\hat{\beta}^{c}\right) \\
-0.227 \\
{[0.070]}\end{array}$ & $\begin{array}{c}\left(\hat{\beta}^{3}-\hat{\beta}^{c}\right) \\
-0.308 \\
{[0.047]}\end{array}$ & - \\
\hline & & $\left(\hat{\beta}^{2}-\hat{\beta}^{1}\right)$ & $\left(\hat{\beta}^{3}-\hat{\beta}^{2}\right)$ & \\
\hline $\begin{array}{l}\text { Diff-in-Diff Estimate } \\
\text { [p-value] }\end{array}$ & & $\begin{array}{l}-0.138 \\
{[0.060]} \\
\end{array}$ & $\begin{array}{l}-0.081 \\
{[0.494]}\end{array}$ & - \\
\hline C. Severe Stunting $(\mathrm{HAZ}<-3)$ & $\hat{\beta}^{1}$ & $\hat{\beta}^{2}$ & $\hat{\beta}^{3}$ & $\hat{\beta}^{c}$ \\
\hline $\begin{array}{l}\text { Duration of PMT in Community (months) x100 } \\
\text { (standard error) }\end{array}$ & $\begin{array}{c}0.085 \\
(0.022)\end{array}$ & $\begin{array}{l}-0.065 \\
(0.039)\end{array}$ & $\begin{array}{l}-0.095 \\
(0.075)\end{array}$ & $\begin{array}{l}0.190^{* *} \\
(0.084)\end{array}$ \\
\hline $\begin{array}{l}\text { Diff-in-Diff Estimate x100 } \\
\text { [p-value] }\end{array}$ & $\begin{array}{c}\left(\hat{\beta}^{1}-\hat{\beta}^{c}\right) \\
-0.105 \\
{[0.236]}\end{array}$ & $\begin{array}{c}\left(\hat{\beta}^{2}-\hat{\beta}^{c}\right) \\
-0.255 \\
{[0.005]}\end{array}$ & $\begin{array}{c}\left(\hat{\beta}^{3}-\hat{\beta}^{c}\right) \\
-0.285 \\
{[0.010]}\end{array}$ & - \\
\hline & & $\left(\hat{\beta}^{2}-\hat{\beta}^{1}\right)$ & $\left(\hat{\beta}^{3}-\hat{\beta}^{2}\right)$ & \\
\hline $\begin{array}{l}\text { Diff-in-Diff Estimate x100 } \\
\text { [p-value] }\end{array}$ & & $\begin{array}{l}-0.150 \\
{[0.001]} \\
\end{array}$ & $\begin{array}{l}-0.305 \\
{[0.712]} \\
\end{array}$ & $\begin{array}{l}- \\
-\end{array}$ \\
\hline \multicolumn{5}{|c|}{$\begin{array}{l}\text { Notes: Standard errors robust to arbitrary within community (village) correlation in parentheses. }{ }^{* * *} \mathrm{p}<0.01 \\
{ }^{* *} \mathrm{p}<0.05,{ }^{*} \mathrm{p}<0.1 . \mathrm{P} \text {-value for diff-in-diff parameter in bracket. Significant diff-in-diff estimates appear in } \\
\text { bold. Regressions also include year dummy, program dummy, gender, age (a quadratic measured in } \\
\text { months), per capita expenditure (In), parental height, parental education, household demographic } \\
\text { variables (male head, number of children, number of female and male adult), community characteristics } \\
\text { (distance to bus station, whether main road is asphalt, availability of sewage and piped water. All } \\
\text { specifications control for community fixed-effects. Source: IFLS } 1997 \text { and } 2000 \text { (N=7455). }\end{array}$} \\
\hline
\end{tabular}


Table A.11. Estimated Impact at Different Levels of Program Duration (Ref Group: CDC 2000)

Panel A: Impact Calculated from $\left(\hat{\beta}^{1}-\hat{\beta}^{c}\right)$

\begin{tabular}{lcccc}
\hline Percentile in & Program & \multicolumn{3}{c}{ Estimated Impact } \\
\cline { 3 - 5 } $\begin{array}{l}\text { Distribution } \\
\text { of Duration }\end{array}$ & $\begin{array}{c}\text { Duration } \\
\text { (Months) }\end{array}$ & $\begin{array}{c}\text { Height-for-Age } \\
\text { (SD) }\end{array}$ & $\begin{array}{c}\text { \% Moderate } \\
\text { Stunting x100 }\end{array}$ & $\begin{array}{c}\text { \% Severe } \\
\text { Stunting } \times 100\end{array}$ \\
\hline $10^{\text {th }}$ & 0.67 & - & - & - \\
$25^{\text {th }}$ & 1.46 & - & - & - \\
$50^{\text {th }}$ & 6.47 & - & - & - \\
$75^{\text {th }}$ & 13.65 & - & - & - \\
$90^{\text {th }}$ & 14.80 & - & - & - \\
\hline
\end{tabular}

Panel B: Impact Calculated from $\left(\hat{\beta}^{2}-\hat{\beta}^{c}\right)$

\begin{tabular}{|c|c|c|c|c|}
\hline \multirow{2}{*}{$\begin{array}{l}\text { Percentile in } \\
\text { Distribution } \\
\text { of Duration }\end{array}$} & \multirow{2}{*}{$\begin{array}{l}\text { Program } \\
\text { Duration } \\
\text { (Months) }\end{array}$} & \multicolumn{2}{|c|}{ Estimated Impact } & \multirow[b]{2}{*}{$\begin{array}{c}\% \text { Severe } \\
\text { Stunting x100 }\end{array}$} \\
\hline & & $\begin{array}{l}\text { Height-for-Age } \\
\text { (SD) }\end{array}$ & $\begin{array}{c}\text { \% Moderate } \\
\text { Stunting x100 }\end{array}$ & \\
\hline $10^{\text {th }}$ & 0.67 & 0.004 & -0.152 & -0.171 \\
\hline $25^{\text {th }}$ & 1.46 & 0.009 & -0.331 & -0.372 \\
\hline $50^{\text {th }}$ & 6.47 & 0.039 & -1.469 & -1.650 \\
\hline $7^{\text {th }}$ & 13.65 & 0.082 & -3.351 & -3.774 \\
\hline $90^{\text {th }}$ & 14.80 & 0.089 & -7.888 & -5.121 \\
\hline
\end{tabular}

Panel C: Impact Calculated from $\left(\hat{\beta}^{3}-\hat{\beta}^{c}\right)$

\begin{tabular}{lcccc}
\hline Percentile in & Program & \multicolumn{3}{c}{ Estimated Impact } \\
\cline { 3 - 5 } $\begin{array}{l}\text { Distribution } \\
\text { of Duration }\end{array}$ & $\begin{array}{c}\text { Duration } \\
\text { (Months) }\end{array}$ & $\begin{array}{c}\text { Height-for-Age } \\
(\text { SD) }\end{array}$ & $\begin{array}{c}\text { \% (Moderate } \\
\text { Stunting } \times 100)\end{array}$ & $\begin{array}{c}\% \text { (Severe } \\
\text { Stunting x100) }\end{array}$ \\
\hline $10^{\text {th }}$ & 0.67 & 0.005 & -0.206 & -0.191 \\
$25^{\text {th }}$ & 1.46 & 0.012 & -0.450 & -0.416 \\
$50^{\text {th }}$ & 6.47 & 0.052 & -1.993 & -1.844 \\
$75^{\text {th }}$ & 13.65 & 0.109 & -4.204 & -3.890 \\
$90^{\text {th }}$ & 14.80 & 0.118 & -4.558 & -4.218 \\
\hline
\end{tabular}

Notes: The impacts are based on difference-in-difference estimates shown in Tables 9 and 10 above. Panel A shows impact on 12 to 23 month old children calculated by coefficients on this treatment group with the control group, and Panel B shows impact of the 12-24 month treatment, calculated by differencing the effects of treatment on the 12 to 24 month group with the 6 to 12 month group. The estimated impacts are based on models that control for presence of a pre-natal program when children were in utero. 


\section{Table A12. Control Experiment to Assess whether Results Reflect a Trend (Ref Group: CDC 2000)}

Panel A. Impact of PMT on Height for Age

\begin{tabular}{lccc}
\hline Age at Time of Survey & $\begin{array}{c}\text { Control 1 } \\
60-95 \\
\text { Months }\end{array}$ & $\begin{array}{c}\text { Control 2 } \\
96-120 \\
\text { Months }\end{array}$ & Difference \\
\hline Months of Community Exposure to PMT & $-0.010^{* *}$ & -0.004 & -0.005 \\
& $(0.004)$ & $(0.004)$ & {$[0.346]$} \\
\hline
\end{tabular}

Panel B. Impact of PMT on Moderate Stunting

Months of Community Exposure to PMT x100
0.215

(0.190)
0.269

$(0.162)$
$-0.054$

[0.821]

\section{Panel C. Impact of PMT on Severe Stunting}

Months of Community Exposure to PMT x100
$0.353^{* *}$

(0.171)
0.094

(0.140)
0.259

[0.221]

Notes: Standard errors robust to arbitrary within community (village) correlation in parentheses. ${ }^{* * *}$ $\mathrm{p}<0.01,{ }^{* *} \mathrm{p}<0.05,{ }^{*} \mathrm{p}<0.1$. P-value for diff-in-diff parameter in bracket. Significant diff-in-diff estimates appear in bold. Regressions also include year dummy, program dummy, presence of prenatal program, gender, age (a quadratic measured in months), per capita expenditure (ln), parental height, parental education, household demographic variables (male head, number of children, number of female and male adult), community characteristics (distance to bus station, whether main road is asphalt, availability of sewage and piped water. All specifications control for community fixed-effects. Source: IFLS 1997 and $2000(\mathrm{~N}=5659)$. 


\section{Table A.13. Impact of PMT on Height-for-Age (HAZ) and \\ Stunting (HAZ<-2 and HAZ<-3): Boy and Girls \\ (Ref Group: CDC 2000)}

\begin{tabular}{|c|c|c|c|c|c|c|c|c|c|}
\hline \multirow{2}{*}{$\begin{array}{l}\text { Panel A. Program Parameter } \\
\text { Duration of PMT in the } \\
\text { Community(months) }\end{array}$} & \multicolumn{2}{|c|}{ Height-for-Age } & \multirow[t]{2}{*}{ sig } & \multicolumn{2}{|c|}{$\begin{array}{c}\text { Moderate } \\
\text { Stunting } \\
(\mathrm{HAZ}<-2) \times 100\end{array}$} & \multirow[t]{2}{*}{ sig } & \multicolumn{2}{|c|}{$\begin{array}{c}\text { Severe } \\
\text { Stunting } \\
(\mathrm{HAZ}<-3) \times 100\end{array}$} & \multirow[t]{2}{*}{ sig } \\
\hline & Boy & Girl & & Boy & Girl & & Boy & Girl & \\
\hline $\begin{array}{l}\text { Treatment: } \\
\text { 6-11 months }\left(\hat{\beta}^{1}\right)\end{array}$ & $\begin{array}{l}-0.010^{* * *} \\
(0.003)\end{array}$ & $\begin{array}{l}-0.004 \\
(0.003)\end{array}$ & & $\begin{array}{l}0.121 \\
(0.084)\end{array}$ & $\begin{array}{l}-0.030 \\
(0.089)\end{array}$ & & $\begin{array}{l}0.111 \\
(0.050)\end{array}$ & $\begin{array}{l}0.048 \\
(0.054)\end{array}$ & \\
\hline $12-23$ months $\left(\hat{\beta}^{2}\right)$ & $\begin{array}{l}0.003 \\
(0.003)\end{array}$ & $\begin{array}{l}-0.002 \\
(0.003)\end{array}$ & & $\begin{array}{l}-0.183^{*} \\
(0.098)\end{array}$ & $\begin{array}{l}0.009 \\
(0.099)\end{array}$ & & $\begin{array}{l}-0.138 \\
(0.073)\end{array}$ & $\begin{array}{l}0.002 \\
(0.069)\end{array}$ & \\
\hline $24-59$ months $\left(\hat{\beta}^{3}\right)$ & $\begin{array}{l}0.007^{*} \\
(0.004)\end{array}$ & $\begin{array}{l}-0.001 \\
(0.004)\end{array}$ & & $\begin{array}{l}-0.277^{*} \\
(0.145)\end{array}$ & $\begin{array}{l}-0.050 \\
(0.150)\end{array}$ & & $\begin{array}{l}-0.271^{* * *} \\
(0.103)\end{array}$ & $\begin{array}{l}0.088 \\
(0.098)\end{array}$ & \\
\hline $\begin{array}{l}\text { Control: } \\
60-95 \text { months }\left(\hat{\beta}^{c}\right)\end{array}$ & $\begin{array}{l}-0.008^{* *} \\
(0.004)\end{array}$ & $\begin{array}{l}-0.004 \\
(0.004)\end{array}$ & & $\begin{array}{l}0.188 \\
(0.159)\end{array}$ & $\begin{array}{l}-0.089 \\
(0.161)\end{array}$ & & $\begin{array}{l}0.195^{*} \\
(0.108)\end{array}$ & $\begin{array}{l}0.180^{*} \\
(0.111)\end{array}$ & \\
\hline $\begin{array}{l}\text { Panel B. Diff-in-Diff } \\
\text { Parameter }\end{array}$ & & & & & & & & & \\
\hline$\left(\hat{\beta}^{1}-\hat{\beta}^{c}\right)$ & $\begin{array}{l}-0.002 \\
{[0.604]}\end{array}$ & $\begin{array}{c}0.000 \\
{[0.973]}\end{array}$ & & $\begin{array}{l}-0.067 \\
{[0.700]}\end{array}$ & $\begin{array}{l}-0.119 \\
{[0.498]}\end{array}$ & & $\begin{array}{l}-0.084 \\
{[0.472]}\end{array}$ & $\begin{array}{c}-0.132 \\
{[0.267]}\end{array}$ & \\
\hline$\left(\hat{\beta}^{2}-\hat{\beta}^{c}\right)$ & $\begin{array}{c}0.011 \\
{[0.016]}\end{array}$ & $\begin{array}{c}0.002 \\
{[0.663]}\end{array}$ & & $\begin{array}{l}-0.370 \\
{[0.041]}\end{array}$ & $\begin{array}{l}-0.189 \\
{[0.654]}\end{array}$ & & $\begin{array}{l}-0.334 \\
{[0.010]}\end{array}$ & $\begin{array}{l}-0.178 \\
{[0.165]}\end{array}$ & \\
\hline$\left(\hat{\beta}^{3}-\hat{\beta}^{c}\right)$ & $\begin{array}{c}0.014 \\
{[0.007]}\end{array}$ & $\begin{array}{l}0.003 \\
{[0.561]}\end{array}$ & & $\begin{array}{l}-0.465 \\
{[0.031]}\end{array}$ & $\begin{array}{l}-0.139 \\
{[0.519]}\end{array}$ & & $\begin{array}{l}-0.466 \\
{[0.002]}\end{array}$ & $\begin{array}{l}-0.092 \\
{[0.529]}\end{array}$ & + \\
\hline$\left(\hat{\beta}^{2}-\hat{\beta}^{1}\right)$ & $\begin{array}{c}0.013 \\
{[0.000]}\end{array}$ & $\begin{array}{c}0.002 \\
{[0.612]}\end{array}$ & ++ & $\begin{array}{l}-0.304 \\
{[0.007]}\end{array}$ & $\begin{array}{c}0.038 \\
{[0.733]}\end{array}$ & + & $\begin{array}{l}-0.250 \\
{[0.001]}\end{array}$ & $\begin{array}{l}-0.046 \\
{[0.545]}\end{array}$ & ++ \\
\hline$\left(\hat{\beta}^{3}-\hat{\beta}^{2}\right)$ & $\begin{array}{c}0.004 \\
{[0.393]}\end{array}$ & $\begin{array}{c}0.001 \\
{[0.793]}\end{array}$ & & $\begin{array}{c}-0.094 \\
{[0.568]}\end{array}$ & $\begin{array}{l}-0.059 \\
{[0.169]}\end{array}$ & & $\begin{array}{c}-0.132 \\
{[0.275]}\end{array}$ & $\begin{array}{l}0.085 \\
{[0.454]}\end{array}$ & \\
\hline \# of Obs & 3823 & 3632 & & 3823 & 3632 & & 3823 & 3632 & \\
\hline
\end{tabular}

Notes: Standard errors robust to arbitrary within community (village) correlation in parentheses. ${ }^{* * *} \mathrm{p}<0.01,{ }^{* *}$ $\mathrm{p}<0.05,{ }^{*} \mathrm{p}<0.1$. P-value for diff-in-diff parameter in bracket. $\left({ }^{+++}\right),\left({ }^{++}\right)$, and $\left({ }^{+}\right)$respectively indicate $1 \%, 5 \%$ and $10 \%$ significant difference between diff-in-diff parameter of boy and girl. Regressions also include year dummy, program dummy, control for prenatal program, gender, age (a quadratic measured in months), per capita expenditure (ln), parental height, parental education, household demographic variables (male head, number of children, number of female and male adult), community characteristics (distance to bus station, whether main road is asphalt, availability of sewage and piped water. All specifications control for community fixed-effects. Source: IFLS 1997 and 2000. 
Table A.14. Estimated Impact on Boys' Nutritional Status at Different Levels

of Program Duration

(Ref Group: CDC 2000)

Panel A: Impact Calculated from $\left(\hat{\beta}^{1}-\hat{\beta}^{c}\right)$

\begin{tabular}{lcccc}
\hline Percentile in & Program & \multicolumn{3}{c}{ Estimated Impact } \\
\cline { 3 - 5 } $\begin{array}{l}\text { Distribution } \\
\text { of Duration }\end{array}$ & $\begin{array}{c}\text { Duration } \\
\text { (Months) }\end{array}$ & $\begin{array}{c}\text { Height-for-Age } \\
\text { (SD) Moderate }\end{array}$ & $\begin{array}{c}\text { \% Severe } \\
\text { Stunting x100 }\end{array}$ & Stunting x100 \\
\hline $10^{\text {th }}$ & 0.67 & - & - & - \\
$25^{\text {th }}$ & 1.46 & - & - & - \\
$50^{\text {th }}$ & 6.47 & - & - & - \\
$75^{\text {th }}$ & 13.65 & - & - & - \\
$90^{\text {th }}$ & 14.80 & - & - & - \\
\hline
\end{tabular}

Panel B: Impact Calculated from $\left(\hat{\beta}^{2}-\hat{\beta}^{c}\right)$

\begin{tabular}{lcccc}
\hline Percentile in & Program & \multicolumn{3}{c}{ Estimated Impact } \\
\cline { 3 - 5 } $\begin{array}{l}\text { Distribution } \\
\text { of Duration }\end{array}$ & $\begin{array}{c}\text { Duration } \\
\text { (Months) }\end{array}$ & $\begin{array}{c}\text { Height-for-Age } \\
(\mathrm{SD})\end{array}$ & $\begin{array}{c}\text { \% Moderate } \\
\text { Stunting x100 }\end{array}$ & $\begin{array}{c}\text { \% Severe } \\
\text { Stunting } \times 100\end{array}$ \\
\hline $10^{\text {th }}$ & 0.67 & 0.007 & -0.248 & -0.224 \\
$25^{\text {th }}$ & 1.46 & 0.016 & -0.540 & -0.488 \\
$50^{\text {th }}$ & 6.47 & 0.071 & -2.394 & -2.161 \\
$75^{\text {th }}$ & 13.65 & 0.150 & -5.051 & -4.559 \\
$90^{\text {th }}$ & 14.80 & 0.163 & -5.476 & -4.943 \\
\hline
\end{tabular}

Panel C: Impact Calculated from $\left(\hat{\beta}^{3}-\hat{\beta}^{c}\right)$

\begin{tabular}{|c|c|c|c|c|}
\hline \multirow{2}{*}{$\begin{array}{l}\text { Percentile in } \\
\text { Distribution } \\
\text { of Duration }\end{array}$} & \multirow{2}{*}{$\begin{array}{l}\text { Program } \\
\text { Duration } \\
\text { (Months) }\end{array}$} & \multicolumn{2}{|c|}{ Estimated Impact } & \multirow[b]{2}{*}{$\begin{array}{c}\% \text { Severe } \\
\text { Stunting x100 }\end{array}$} \\
\hline & & $\begin{array}{l}\text { Height-for-Age } \\
\text { (SD) }\end{array}$ & $\begin{array}{c}\text { \% Moderate } \\
\text { Stunting x100 }\end{array}$ & \\
\hline $10^{\text {th }}$ & 0.67 & 0.009 & -0.312 & -0.312 \\
\hline $25^{\text {th }}$ & 1.46 & 0.020 & -0.679 & -0.680 \\
\hline $50^{\text {th }}$ & 6.47 & 0.091 & -3.009 & -3.015 \\
\hline $75^{\text {th }}$ & 13.65 & 0.191 & -6.347 & -6.361 \\
\hline 90th & 14.80 & 0.207 & -6.882 & -6.897 \\
\hline
\end{tabular}

Notes: The impacts are based on difference-in-difference estimates shown in Tables 9 and 10 above. Panel A shows impact on 12 to 23 month old children calculated by coefficients on this treatment group with the control group, and Panel B shows impact of the 12-24 month treatment, calculated by differencing the effects of treatment on the 12 to 24 month group with the 6 to 12 month group. The estimated impacts are based on models that control for presence of a pre-natal program when children were in utero. 